\title{
Evaluation of ozonesondes, HALOE, SAGE II and III, Odin- OSIRIS and -SMR, and ENVISAT-GOMOS, -SCIAMACHY and -MIPAS ozone profiles in the tropics from SAOZ long duration balloon measurements in 2003 and 2004
}

\author{
F. Borchi and J.-P. Pommereau \\ CNRS, Service d'Aéronomie, Verrières le Buisson, France \\ Received: 14 July 2006 - Published in Atmos. Chem. Phys. Discuss.: 11 October 2006 \\ Revised: 2 May 2007 - Accepted: 8 May 2007 - Published: 22 May 2007
}

\begin{abstract}
The performances of satellite and sondes ozone measuring instruments available in the tropics between 10 and $26 \mathrm{~km}$ during the southern hemisphere summer in 2003 and 2004, have been investigated by comparison with series of profiles obtained by solar occultation in the visible Chappuis bands using a SAOZ UV-Vis spectrometer carried by long duration balloons. When compared to SAOZ, systematic positive or negative altitude shifts are observed in the satellite profiles, varying from $<50 \mathrm{~m}$ for the GOMOS v6.0b stellar occultation instrument, followed by $+100 / 200 \mathrm{~m}$ for solar occultation systems (SAGE II v6.2, HALOE v19 above $22 \mathrm{~km}$ ), but as large as $-900 \mathrm{~m}$ for the OSIRIS limb viewing system. The ozone relative biases are generally limited, between $-4 \%$ and $+4 \%$, for measurements in the visible Chappuis bands (SAGE II and SAGE III moon v3, GOMOS above $22 \mathrm{~km}$ and OSIRIS), the near IR (HALOE above $22 \mathrm{~km}$ ) and the ozonesondes, but increase to $+5.5 \%$ (SCIAMACHY IUP v1.63) though still in the visible, and $+7 \%$ in the mid-IR (MIPAS NL v4.61) and the submillimetric range (SMR v222). Regarding precision, evaluated statistically from the zonal variability of ozone concentration, the best measurements are found to be those of SAGE II (2\%), followed by HALOE above $22 \mathrm{~km}(3-4 \%)$, then the ozonesondes, SAGE III moon, SCIAMACHY and OSIRIS (4-5\%), GOMOS above $22 \mathrm{~km}$ $(\sim 6 \%)$, MIPAS $(8.5 \%)$ and finally SMR $(16 \%)$. Overall, all satellite ozone measurements appear to be of little utility in the tropical troposphere except those of SAGE II (and eventually SAGE III), though low biased by $50 \%$ and of limited (50\%) precision.
\end{abstract}

Correspondence to: F. Borchi

(borchi@aerov.jussieu.fr)

\section{Introduction}

Because of the many dynamical and chemical processes involved, i.e. quasi-horizontal transport from mid-latitude, convective uplift from the surface, photochemical production by precursors, and potential destruction by very short lived species such as bromine and iodine compounds, the knowledge of ozone concentration changes in the tropical upper troposphere / lower stratosphere (UT/LS) and particularly in the Tropopause Tropical Layer (TTL) is a prerequisite for understanding possible climatic and long term ozone changes in the future. However and although long series of ozone profile measurements are available for a long time from space-borne instruments such as SAGE II since 1984 (Mauldin et al., 1985), HALOE since 1992 (Russell et al., 1993), complemented by the SHADOZ tropical ozonesonde network since 1998 involving now eleven stations (Thompson et al., 2003), the ozone distribution and its variations are still poorly characterised in the TTL. This is because of the many limitations of remote sensing observations from orbit in tropical areas such as increased Rayleigh atmospheric attenuation, high altitude clouds, low temperature, high humidity and dense aerosols and for ozonesondes, their necessarily limited number. For example, although a 8-year comparison between HALOE and SAGE II shows RMS differences not exceeding $4-12 \%$ through most of the stratosphere, larger differences ( $>15 \%$, HALOE low compared to SAGE II) are systematically observed below $22 \mathrm{~km}$ in the tropical lower stratosphere which never received satisfactory explanations (Morris et al., 2002). Another example is the $40-60 \%$ low bias of SAGE II ozone in the upper tropical troposphere compared to ozonesondes reported by Kar et al. (2002) and Wang et al. (2002), attributed by these authors to the high sensitivity of the retrieved ozone abundance to the background (electronic offset) of the SAGE II channel.

Published by Copernicus Publications on behalf of the European Geosciences Union. 
More recently, the relative performances of SAGE II, HALOE and the SHADOZ ozonesondes in the tropics have been studied by comparison with accurate measurements of a SAOZ UV-Visible spectrometer carried by long duration balloons flown in 2001 and 2003 at $20^{\circ} \mathrm{S}$ (Borchi et al., 2005). The agreement with $\mathrm{SAOZ}$ was found excellent in the stratosphere ( $2 \%$ precision, $+2-4 \%$ ozone bias, $+150 \mathrm{~m}$ altitude bias for SAGE II; $4 \%$ precision, $<1 \%$ ozone bias, $<100 \mathrm{~m}$ altitude bias for HALOE; and 5\% precision, $-4 \%$ bias and $+300 \mathrm{~m}$ in altitude for the sondes), but degrading rapidly for the two space-borne instruments, below $22 \mathrm{~km}$ $(-40 \%$ at $18 \mathrm{~km})$ for HALOE, and below $19 \mathrm{~km}$ for SAGE II, displaying a low bias of $50-60 \%$ compared to SAOZ in the upper troposphere. The comparison between SAOZ and the ozonesondes in the troposphere is less conclusive. Indeed, the SAOZ ozone concentrations were found to be comparable with those of the sondes at Reunion Island but systematically high biased by $50-60 \%$ at Samoa and Fiji in the Western Pacific. Asides from differences of instrumental arrangements, a possible explanation could be the frequent occurrence of near zero ozone layers in convective clouds over the South Pacific Convergence Zone (SPCZ) because of the ozone destruction at the surface of the ocean (Kley et al., 1996), which could not be seen by SAOZ limited by definition to cloud free areas. A possible systematic overestimation of tropospheric ozone by remote sensing systems was thus suggested over convective areas.

Since 2001 a number of new ozone measuring space instruments have been put into orbit: the Limb viewing visible OSIRIS (Optical Spectrograph and Infrared Imager System) (Warshaw et al., 1996; Llewellyn et al., 1997) and the Limb observing SMR (Sub-Millimetre Radiometer) (Murtagh et al., 2002) both aboard the Swedish-Finish-Canadian-French ODIN satellite launched in February 2001; the NASA SAGE III UV-Vis-near IR spectrometer aboard METEOR III in December 2001 operating by moon occultation in the tropics (McCormick et al., 1991); and finally the ESA ENVISAT satellite in March 2002 carrying the GOMOS (Global Ozone Monitoring by Occultation of Stars) stellar occultation (Bertaux et al., 1991; Bertaux et al., 2001), the limb viewing SCIAMACHY (SCanning Imaging Absorption spectrometer for Atmospheric CHartographY) UV-Vis spectrometers (Burrows and Chance, 1991; Bovensmann et al., 1999) and the Infra-red Limb viewing MIPAS (Michelson Interferometer for Passive Atmospheric Sounding) (Fischer and Oelhaf, 1996; Harris, 2000).

The objective of the present paper is the evaluation of the performances of all above systems with the method applied already by Borchi et al. (2005), with the data of the 9-day SAOZ flight of February 2003 and those of a new 39-day flight carried in February-April 2004 in the frame of a HIBISCUS project of the European Union dedicated to the study of the impact of convection on the stratosphere (Pommereau et al., 2007).
Section 2 provides a brief description of the SAOZ system and the long duration balloon flights performed in 2003 and 2004 and a recall of the technique developed for deriving the relative contributions of horizontal and vertical transport and measurements errors from the observed ozone zonal variability. Section 3 describes the performances of each ozone measuring system, altitude registration, ozone bias and precision, relative to those of SAOZ: HIBISCUS ozonesondes at Bauru and at the three SHADOZ stations overflown by the balloons, and HALOE, SAGE II and III, Odin-OSIRIS and SMR, and ENVISAT-GOMOS, -SCIAMACHY and -MIPAS instruments into orbit by that time. Section 4 provides a comparison of the relative performances of each of them. Finally, the conclusions of the study are summarised in Sect. 5 .

\section{SAOZ ozone profiles in the tropics}

SAOZ is a balloon borne diode array UV-Visible spectrometer for remote $\mathrm{O}_{3}$ and $\mathrm{NO}_{2}$ observations by solar occultation (Pommereau and Piquard, 1994). In the present application it was flown aboard long duration Infra-Red Montgolfier (MIR) balloons operated by the Centre National d'Etudes Spatiales (CNES). The data used here are those of two flights launched from Bauru at $22^{\circ} \mathrm{S}$ in Brazil during the SH summer season in February-March 2003 and 2004, similar to the 34-day flight already performed in 2001 (Borchi et al., 2005). The first in 2003 lasted for 9 days at about $20^{\circ} \mathrm{S}$ across the Pacific before being brought down by a hurricane over the Coral Sea, while the second in 2004 flew for 39 days for one and half circumnavigation between $20^{\circ} \mathrm{S}$ and $9^{\circ} \mathrm{S}$.

\subsection{MIR SAOZ balloon flight in 2003 and 2004}

Ozone profiles are obtained by solar occultation in the visible Chappuis bands in the $450-620 \mathrm{~nm}$ spectral range. The spectra are analysed by the differential optical absorption technique (DOAS). The profiles are retrieved by onion peeling after calculating the light path by ray tracing. Compared to a satellite, the advantage of a balloon moving slowly is to allow the exposure to vary from $0.5 \mathrm{~s}$ to $52 \mathrm{~s}$ for compensating the strong increase of attenuation at low tangent height, allowing the measurements to be continued down to cloud top or to about $6 \mathrm{~km}$ in clear conditions. A description of the SAOZ instrument (300-650 nm range, $1.1 \mathrm{~nm}$ resolution, 3 pixels over-sampling) is given in Borchi et al. (2005). Although very similar in most aspects, the SAOZ payload flown in 2004 was using a slightly different spectrometer extended to $1000 \mathrm{~nm}$ for the measurement of water vapour around $940 \mathrm{~nm}(400-1000 \mathrm{~nm}$ range, $1.2 \mathrm{~nm}$ resolution, 1.7 pixels over-sampling). However, the change has no impact on ozone measurements in the broad ( $30 \mathrm{~nm}$ large) Chappuis bands features. The altitude is a geometric altitude above Mean Sea Level (MSL) directly related to that of the GPS 3D location (Larsen LP from Trimble; horizontal accuracy $<8 \mathrm{~m}$ 

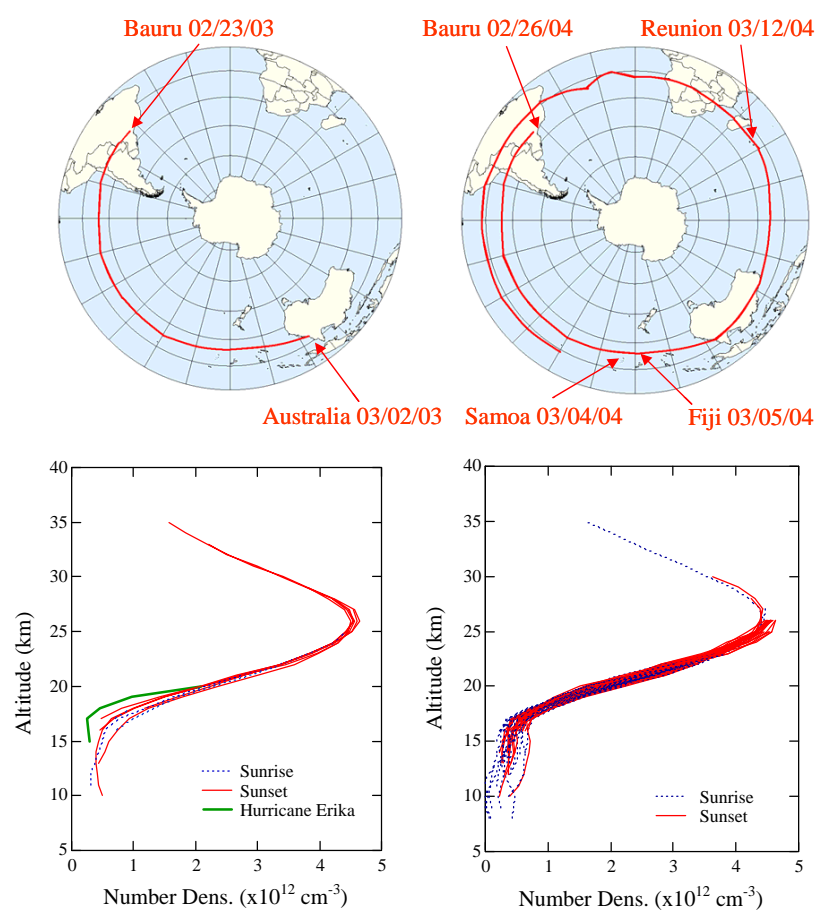

Fig. 1. Balloon trajectories (top) and ozone profiles (bottom) in 2003 (left) and 2004 (right).

$(90 \%)$, vertical $<16 \mathrm{~m}(90 \%))$, from which the SZA at the location of the balloon and then the tangent height are derived. However, the GPS MSL altitude refers to an Earth Gravitational Model, which differs from the real MSL by few meters on $90 \%$ of the globe but $+20 /-40 \mathrm{~m}$ in extreme cases from recent satellite altimetric measurements. The atmospheric density profile used in the calculation of tangent height after refraction is that of the standard atmosphere at $15^{\circ} \mathrm{N}$. Compared to this, the average ECMWF (European Centre for Medium-range Weather Forecast) density at the location of the MIR is larger by $6 \%$ with a peak to peak dispersion of $\pm 6 \%$ resulting in an average high bias of the SAOZ altitude registration of $24 \mathrm{~m}$ at $20 \mathrm{~km}$ and $72 \mathrm{~m}$ at $15 \mathrm{~km}$. The overall uncertainty of the SAOZ altitude registration is thus $+64 /-16 \mathrm{~m}$ at $20 \mathrm{~km}$ and $+140 /-16 \mathrm{~m}$ at $15 \mathrm{~km}$. This is very consistent with the average shift of $+30 \pm 25 \mathrm{~m}$ bias between $17-24 \mathrm{~km}$ found between SAOZ and the measurements of an ozone lidar during the overpass of a MIR-SAOZ over the NDSC station of Reunion Island (Borchi et al., 2005). The vertical resolution of the measurements is $1.4 \mathrm{~km}$ corresponding to the half-width of the solar disk brightness, while concentrations are retrieved within $1 \mathrm{~km}$ thick atmospheric shells. Data contaminated by clouds are removed by looking at the atmospheric extinction at $615 \mathrm{~nm}$.

The precision of the SAOZ ozone retrievals estimated from fitting errors of the spectral analysis is $1.5 \%$ at $20 \mathrm{~km}$ degrading to $5 \%$ at $17.5 \mathrm{~km}, 10 \%$ at $15 \mathrm{~km}$ and $23 \%$ at $10 \mathrm{~km}$, to which a systematic error of $1.5 \%$ has to be added for accu-

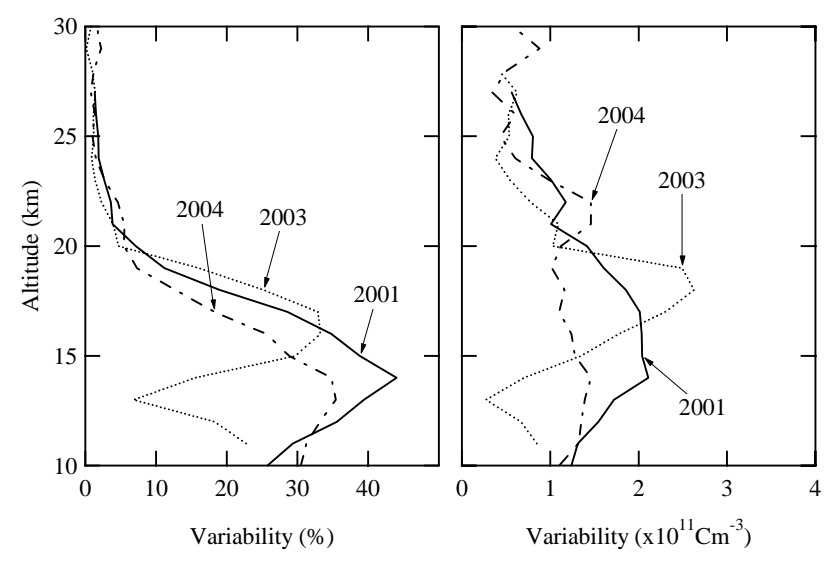

Fig. 2. Zonal variability of ozone concentration in 2001, 2003 (Pacific only) and 2004. Left: relative standard deviation in percent compared to the mean profile; Right: standard deviation in number density.

racy corresponding to the uncertainty of the ozone absorption cross-sections used (Borchi et al., 2005).

The data used here are those obtained during two flights at the tropics launched from Bauru, Brazil $\left(22^{\circ} \mathrm{S}, 49^{\circ} \mathrm{W}\right)$, the first on 23 February 2003 for the preparation of the HIBISCUS campaign, and the second on 26 February 2004 during the following main campaign (http://www.aerov.jussieu. fr/projet/HIBISCUS/). The first lasted for 9 days only, at almost constant latitude $\left(22^{\circ} \pm 1^{\circ} \mathrm{S}\right)$, providing 11 useful profiles across the Pacific before being lost over a hurricane. The second lasted for 39 days, resulting in 70 useful profiles (roughly half at sunrise, half at sunset) between $9^{\circ} \mathrm{S}$ and $21^{\circ} \mathrm{S}$, before falling over the Pacific Convergence Zone. The trajectories of the balloons in the summer stratospheric Easterlies and the ozone profiles recorded along the flights at sunset and sunrise, are shown in Fig. 1. Only the first thirtyone profiles of 2004 within the $15-21^{\circ} \mathrm{S}$ latitude range are being used in this study which could be readily compared with those observed within $15-25^{\circ} \mathrm{S}$ in 2001 and $20-23^{\circ} \mathrm{S}$ in 2003 (Borchi et al., 2005).

\subsection{Ozone variability along a latitudinal circle}

The zonal variability of ozone concentration along the flights in 2001, 2003 and 2004 is shown in Fig. 2 (relative standard deviation in percent on the left, standard deviation in number density on the right). In the stratosphere, above $20 \mathrm{~km}$, the figures are very similar on the three years showing little variability $(<5 \%)$, but increasing rapidly below $20 \mathrm{~km}$, reaching a maximum on the two long circumnavigating flights, of $45 \%$ in 2001 and $35 \%$ in 2004 at $14-15 \mathrm{~km}$ at about the average altitude of the tropopause and then decreasing at lower altitude. The picture is slightly different on the nine days flight in 2003 where the measurements are limited to the Pacific. In this region, the variability displays a maximum around $17-18 \mathrm{~km}$, 

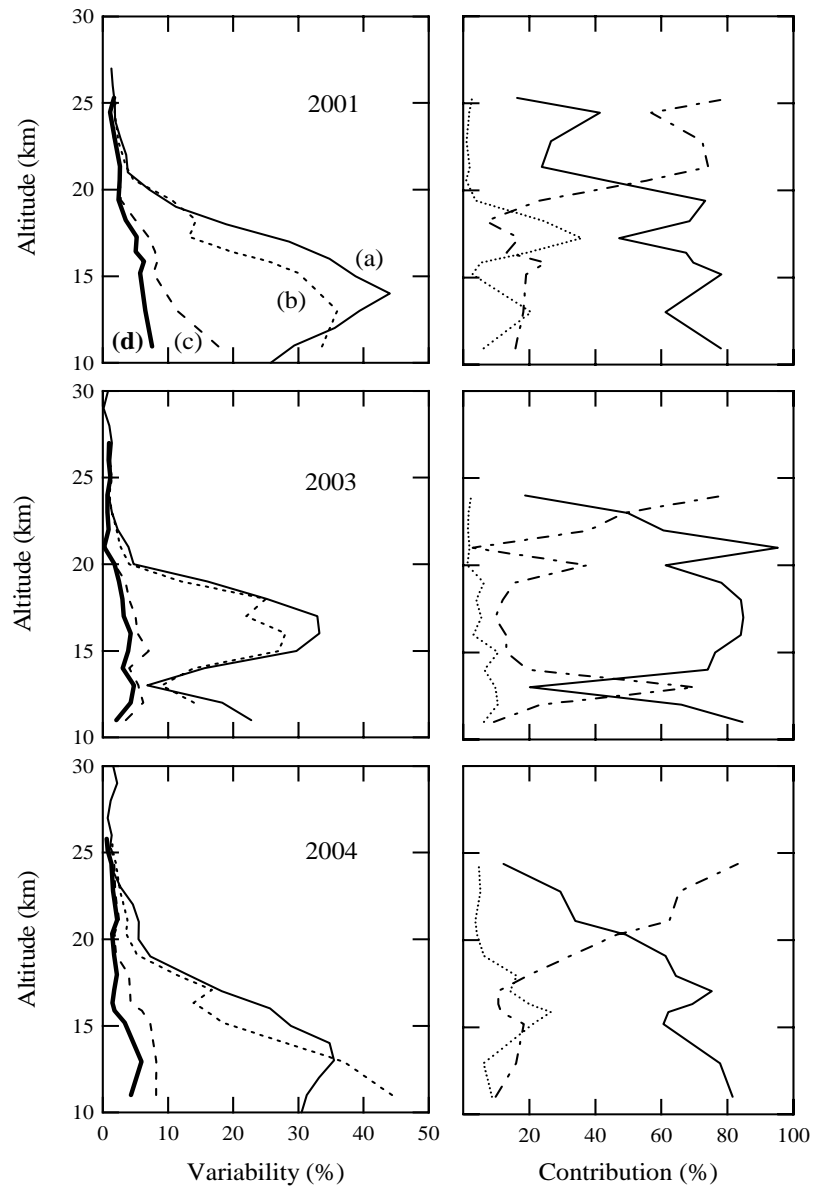

Fig. 3. Analysis of contributions to zonal variability (relative standard deviation) of ozone in 2001 (top), 2003 (middle) and 2004 (bottom). Left: percent variability (a) number density at constant altitude (b) mixing ratio on isentropic surfaces; (c) after removing horizontal transport; (d) after removing vertical and horizontal transport. Right: relative contributions of horizontal (solid line) and vertical (dotted) transport and measurement errors (dotted-dashed) to total variability.

higher than the zonal average of long duration flights, largely due to the upward displacement of the ozone profile associated to the hurricane Erika (Fig. 1). The minimum variability below is little significant since it is derived from three profiles only, all over the non-convective eastern Pacific, the western part being covered by high altitude clouds.

Apart from random errors, several mechanisms could contribute to the variability, i.e. horizontal and vertical transport, convective lifting of ozone poor air from oceanic surfaces and photochemical production by precursors. A method for analysing and separating atmospheric and instrumental contributions in the ozone measurements has been proposed by Borchi et al. (2005) based on a multiple regression with proxies of horizontal and vertical transport. The proxy used for horizontal transport is potential vorticity (PV) on isentropic surfaces provided by the MIMOSA high-resolution contour advection model initialised with ECMWF wind fields (Hauchecorne et al., 2002) interpolated at the location of the SAOZ tangent points. For vertical transport, the proxy used is the altitude difference between $370 \mathrm{~K}$ and $340 \mathrm{~K}$ isentropic levels issued from ECMWF operational analyses at the location of the SAOZ tangent height. It is an indicator of the presence of convection in the troposphere below the balloon and thus of possible overshooting of ozone poor air in the Tropical Tropopause Layer (TTL) or even in the lower stratosphere, currently not captured by the models. The same proxy is used for all altitude levels.

Ozone number densities at geometric altitude as shown in Fig. 1 are first converted in mixing ratios (MR) on isentropic surfaces. The contribution of quasi-horizontal and convective transport is then evaluated by correlating ozone, PV and $\Delta Z_{370-340 \mathrm{~K}}$ changes at each level, following the equation:

$\Delta \mathrm{O}_{3}(\Theta)=\alpha(\Theta) . \Delta \mathrm{PV}(\Theta)+\beta(\Theta) . \Delta \mathrm{Z}_{370-340 . \mathrm{K}}$

where $\Delta \mathrm{PV}(\Theta)$ is the variability of potential vorticity, $\alpha(\Theta)$ the slope of the linear regression between ozone MR and MIMOSA PV, and $\beta(\Theta)$ the slope of the linear regression between ozone MR and $\Delta Z_{370-340 \mathrm{~K}}$, at a $\Theta$ isentropic level. The calculations are made on 16 isentropic levels between 335 and $650 \mathrm{~K}$, corresponding to a vertical resolution of $\sim 700-1000 \mathrm{~m}$.

The results of the regression applied to the SAOZ measurements in 2001, 2003 and 2004 are depicted in Fig. 3, where the left panel shows the residual variability after each step of the calculation: (a) number density at geometric levels; (b) mixing ratio on isentropic surface; (c) after removal of horizontal transport (PV) and (d) residual after removing also vertical transport. The right panel shows the relative percent contributions of horizontal and vertical transport as well as of the residual representing the random error of the measurements and possibly also other mechanism, e.g. photochemical production. The results are very similar for the two long circumnavigating flights in 2001 and 2004 displaying a large $60-70 \%$ contribution of horizontal transport below $20 \mathrm{~km}$, and a smaller impact of vertical transport of 15 $25 \%$ limited to the $14-20 \mathrm{~km}$ altitude levels. This suggests an overshooting ozone poor air up to $19-20 \mathrm{~km}$ in the Tropical Tropopause layer (TTL) and the lower stratosphere. The absence of signature of convective transport below is simply due to the fact that the ozone mixing ratio is constant in the troposphere. A vertical displacement has thus little impact on the profile. If the residual variability, which may still include some contribution from ozone photochemical production, is adopted as an indicator of random error, the precision of the SAOZ ozone measurements would be $2 \%$ in the stratosphere, $5-6 \%$ at the tropopause and $7-8 \%$ at $12 \mathrm{~km}$ in the upper troposphere. These figures are very consistent with those estimated from the error of the spectral fitting of $1.5 \%$ in the stratosphere and $5-6 \%$ at the tropopause, but significantly better in the upper troposphere than the estimation of $10 \%$ at 
Table 1. Date of SAOZ profiles $(\mathrm{sr}=$ sunrise, $\mathrm{ss}=$ sunset $)$ and ozonesondes selected ascents in 2004.

\begin{tabular}{lllllll}
\hline Station & SAOZ profiles & Sondes ascents & Time (day) & Lat (deg) & Lon (deg) & Distance $(\mathrm{km})$ \\
\hline Bauru & 27 Feb (sr, ss) & 21, 23, 24 Feb & $3-6$ & $2.1-2.6$ & $11.6-30.6$ & $1235-3210$ \\
Samoa & 4 March (sr, ss) & 4, 5 March & $0-1$ & $4.2-4.8$ & $2.8-5.4$ & $611-734$ \\
Fiji & 5 March (sr, ss) & 4 March & 1 & $1.5-2.4$ & $5.0-12.7$ & $548-1353$ \\
Reunion & 11 March (sr), 12 (sr) & 10, 11 March & $0-2$ & $3.1-4.8$ & $3.1-15.6$ & $475-1717$ \\
\hline
\end{tabular}

$15 \mathrm{~km}$ and $23 \%$ at $10 \mathrm{~km}$. The identified reason for this is the presence of water vapour lines introducing systematic errors in the spectral analysis but of small impact on the precision of ozone measurements.

\section{Evaluation of relative performances of other systems}

A number of ozone profiles within the latitude range and during the period of the MIR flights in 2003 and 2004 are available from the SHADOZ ozonesondes and those performed at Bauru during HIBISCUS, from three NASA space instruments, HALOE, SAGE II and III respectively aboard UARS, ERBS and METEOR 3M, from the two OSIRIS and SMR instruments aboard ODIN, and from GOMOS, SCIAMACHY and MIPAS aboard ENVISAT. The performances of each have been studied by comparison with SAOZ after adaptation of vertical resolution by smoothing. Higher resolution measurements are smoothed to the resolution of the other measurement to which they are compared, i.e. ozonesondes of $50 \mathrm{~m}$ sampling adapted to the $1.4 \mathrm{~km} \mathrm{SAOZ}$ resolution or of SAOZ adapted to the broad $2-3 \mathrm{~km}$ satellite limb viewing resolution. For better evaluation of the precision of each instrument the contribution of horizontal transport is removed following the technique applied to $\mathrm{SAOZ}$ as described above. But since the contribution of convective transport is relatively limited, it will be ignored. The mathematical background used in this section is given in Appendix A.

\subsection{Ozonesondes}

A first statistical comparison between SHADOZ ozonesondes (Borchi et al., 2005) at Samoa, Fiji and Reunion Island and SAOZ-MIR flights carried in February and March 2001 and 2003 concluded at (i) a small systematic altitude shift up of the sondes by $300 \mathrm{~m}$ consistent with the known 40$50 \mathrm{~s}$ time constant of the Electrochemical Concentration Cell (ECC) on a balloon ascending at 5-6 m/s (SPARC, 1998, Johnson et al., 2002); (ii) an average relative ozone low bias of $4 \pm 1 \%$ in the stratosphere between 20 and $26 \mathrm{~km}$, and (iii) a $5 \%$ precision. As already explained, at lower altitude in the upper troposphere the SAOZ measurements were found comparable with those of the sondes at Reunion Island but systematically high biased by $50-60 \%$ compared to the ascents of Samoa and Fiji in the high clouds area of the South
Pacific Convergence Zone (SPCZ) suggesting a systematic high bias in remote sensing measurements in oceanic convective clouds areas. This problem has been revisited in 2004 by dedicated ozonesondes ascents during the pass of the balloon over the stations.

\subsubsection{Ozonesondes at Bauru and at three SHADOZ stations in 2004}

The data used here are those of thirteen ozonesondes ascents performed by IPMet and the Danish Meteorological Institute (Pommereau et al., 2007) from Bauru during the HIBISCUS campaign in February and March 2004 and those of special ascents during the overpass of the balloon over the SHADOZ stations of Samoa $\left(14.2^{\circ} \mathrm{S}, 171^{\circ} \mathrm{W}\right)$ and Fiji $\left(18.1^{\circ} \mathrm{S}, 178^{\circ} \mathrm{E}\right)$ in the Western Pacific (S. Oltmans, personal communication) and Reunion Island $\left(21^{\circ} \mathrm{S}, 55.5^{\circ} \mathrm{E}\right)$ in the Indian Ocean (F. Posny, personal communication). For statistical studies several other ascents at the three stations between 23 February and 31 March 2004 available from the SHADOZ database (http://croc.gsfc.nasa.gov/shadoz/), have been added. All ozonesondes are ECC (Electrochemical Concentration Cell) but of various types, i.e. SPC 6A, $2 \%$ unbuffered KI solution at Fiji and Samoa, ENSCI Z 0.5\% buffered at Reunion, and partly SPC 6A partly ENSCI both $1 \%$ buffered at Bauru, and in addition using different correcting factors for pump efficiency. In the following, ozone partial pressure is converted into number density using the radiosonde pressure and temperature. The altitude is a geopotential height derived from the pressure sensor of the sonde. Since the sonde sampling of $50 \mathrm{~m}$ is higher than that of SAOZ, the sonde data have been smoothed with a binomial filter to match the $\mathrm{SAOZ}$ resolution of $1.4 \mathrm{~km}$, and then linearly interpolated to $1 \mathrm{~km}$ steps.

The circumstances of the ozonesondes ascents and the SAOZ measurements are displayed in Table 1. Though the MIR passed close to the stations, because of the time difference with the ascents, the observations are always separated by more than $475 \mathrm{~km}$ in distance. In addition, at several occasions, the SAOZ measurements at the closest distance were limited to altitude levels above the tropopause at $16-17 \mathrm{~km}$ because of the presence of high clouds. Even more difficult to interpret are the SAOZ measurements of Reunion Island close to the powerful Gafilo cyclone present over the area on 


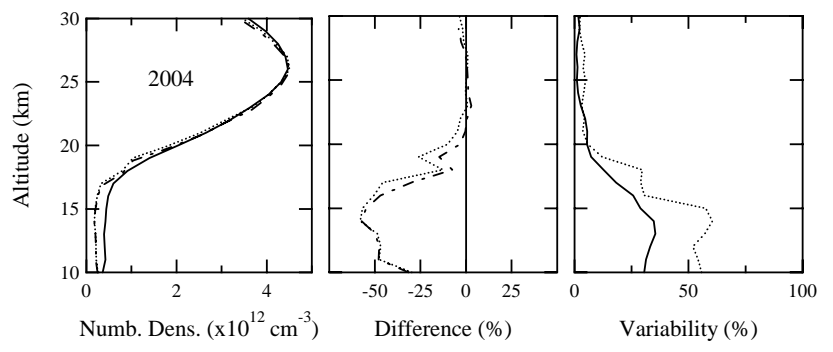

Fig. 4. Comparison between SAOZ and SHADOZ ozonesondes in 2004. From left to right: mean zonal profile, relative percent difference compared to the mean, and relative standard deviation. Solid line: SAOZ; dotted: SHADOZ; dotted-dashed: SHADOZ altitude adjusted.

2-17 March which prevented lidar observations during the period. Indeed, the temperature and ozone profiles of March 10 and March 11 ascents display a large upwelling and cooling of the tropopause compared to the monthly average, and at the opposite, an increase of ozone in the lower stratosphere highly correlated with a PV increase indicative of strong advection from mid-latitude.

\subsubsection{SHADOZ statistical comparison in the stratosphere}

Twelve ascents are available between 23 February and 31 March 2004 at Samoa $\left(14.2^{\circ} \mathrm{S}, 171^{\circ} \mathrm{W}\right)$, Fiji $\left(18.1^{\circ} \mathrm{S}\right.$, $\left.178^{\circ} \mathrm{W}\right)$ and Reunion Island $\left(21^{\circ} \mathrm{S}, 55.5^{\circ} \mathrm{E}\right)$, ignoring those of February 10 and 11 at the latter station because of the cyclone.

The sondes and SAOZ mean profiles, percent difference and relative variability are displayed in Fig. 4 . The analysis confirms the results of 2001 and 2003 displaying a shift up by some $200 \mathrm{~m}$ of the sondes compared to SAOZ, and a $4 \%$ precision. But, after adjustment for the altitude shift, the average relative $\mathrm{O}_{3}$ bias of $+1.5 \%$ in 2004 is different from the $-4 \%$ of 2001 . The possible significance of such difference derived from comparisons with 12 ascents in 2004 and 19 in 2001 of different instrumental arrangement and data processing software, is difficult to access. All which can be safely concluded is that the differences remain within the $\pm 5 \%$ accuracy quoted for the SHADOZ sondes (Thompson et al., 2003).

\subsubsection{Individual overpass comparisons in the troposphere}

On average as shown in Fig. 4, the SAOZ profiles are high biased by some $50 \%$ in the troposphere compared to the sondes. But given the high variability of tropospheric ozone concentration, this is of little meaning. A better approach is to look at collocated profiles above individual stations. The comparison between sondes and SAOZ profiles over each station is displayed in Fig. 5 and the results of the analysis are summarized in Table 2. In the troposphere, the results
Table 2. Ozonesondes-SAOZ percent difference in the stratosphere and the troposphere after altitude adjustment (NA = Not Applicable).

\begin{tabular}{lcc}
\hline Station & Stratosphere & Troposphere \\
\hline Bauru & $-0.9 \pm 5.3$ & NA \\
Samoa & $+2.3 \pm 1.5$ & $-32.7 \pm 16.6$ \\
Fiji & $+2.6 \pm 2.5$ & $-34.0 \pm 13.4$ \\
Reunion & $+3.3 \pm 3.4$ & $-26.0 \pm 24.8$ \\
\hline
\end{tabular}

confirm the analysis of 2001 and 2003 displaying for the two Pacific stations, a high bias of some $30 \%$ of SAOZ compared to the sondes, even for the closest MIR overpass $611 / 734 \mathrm{~km}$ over Samoa. However, a similar high bias of $26 \%$ is found at Reunion Island in 2004 in contrast to $1 \%$ in 2001. In that case, the difference might be partly attributed to a similar lift of low ozone air by the cyclone, which was not be seen by SAOZ more than $500 \mathrm{~km}$ west. Low or even zero ozone layers as frequently reported by the sondes in convective regions have never been observed with the $\mathrm{SAOZ}$ whose measurements are limited to cloud free areas. Although differences of technical arrangements could certainly contribute to differences between ozonesonde stations (e.g. the data processing software of Reunion Island was changed in 2003 for the NOAA/CMDL system), the results of 2004 support the idea of a possible systematic overestimation of average tropospheric ozone in the tropics by remote sensing instruments because of the absence of measurements in the presence of clouds.

\subsection{HALOE}

The HALogen Occultation Experiment (HALOE) aboard the Upper Atmosphere Research Satellite (UARS) launched in September 1991 and still in operation, performs solar occultation measurements to infer mixing ratio profiles of trace gases (Russell et al., 1993). Ozone measurements are carried out in a broadband channel centred at $9.6 \mu \mathrm{m}$. The geometry of the UARS orbit $\left(57^{\circ}\right.$ inclination, circular at $585 \mathrm{~km}$ with orbit period of $96 \mathrm{~min}$ ) results in about 15 sunrises and 15 sunsets daily, with tangent point locations during a day confined to small latitude bands, different for the two events, which cycle over varying extremes, roughly every 36 days. Tangent heights are derived from a solar edge detection system. The error estimates provided in the HALOE data files include random components due to noise and altitude dependent quasi-systematic errors due to uncertainties in aerosol corrections. They vary from about $5-10 \%$ in the middle and upper atmosphere, to about $30 \%$ at $100 \mathrm{hPa}$ (Bhatt et al., 1999). The vertical resolution of $2 \mathrm{~km}$ of HALOE profiles is close to that of SAOZ, and the sampling $0.3 \mathrm{~km}$. 

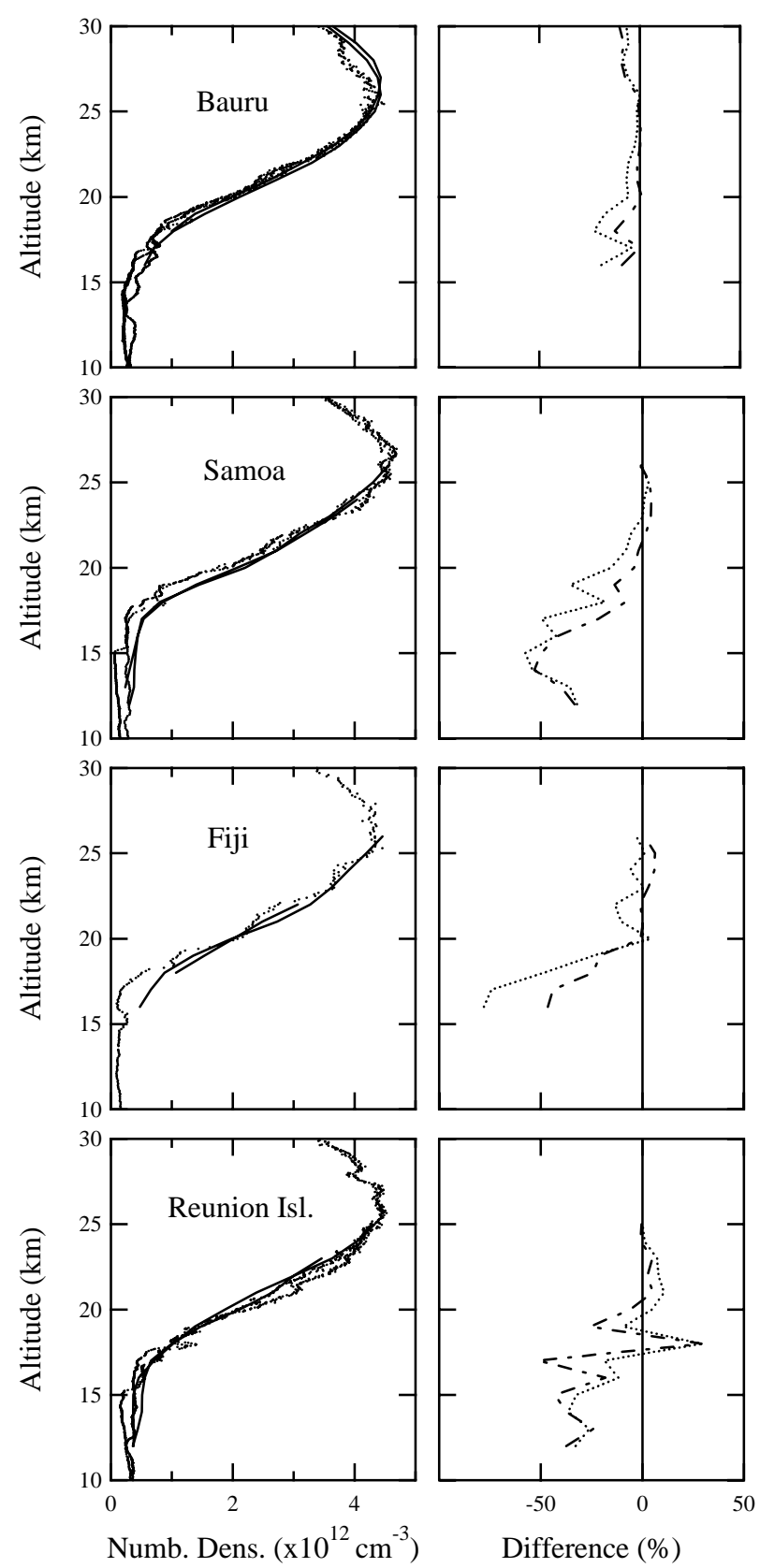

Fig. 5. Comparison of best collocated SAOZ and sondes ozone profiles in 2004. Left: profile; right: percent difference. solid line: SAOZ; dotted: sondes; dotted-dashed: sondes altitude adjusted. From top to bottom: Bauru, Samoa, Fiji and Reunion Island.

A first comparison between HALOE v19 and SAOZ in 2001 and 2003 at the Southern Tropics at $20^{\circ} \pm 5^{\circ} \mathrm{S}$ during the SH summer (Borchi et al., 2005) showed an insignificant ozone bias in the stratosphere between 22 and $26 \mathrm{~km}$ of $+1 \%$ to $-0.7 \%$ depending on the year and the event, a small altitude shift up by $100 \mathrm{~m}$ and a precision of $4 \%$. However, the agreement was observed to degrade rapidly below $22 \mathrm{~km}$,

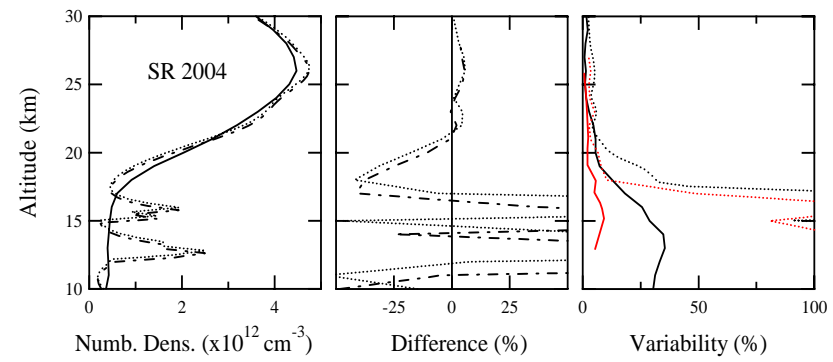

Fig. 6. Comparison between SAOZ and HALOE sunrise ozone in 2004. From left to right: mean zonal profile, relative percent difference, and relative percent standard deviation. Solid line: SAOZ; dotted: HALOE; dotted-dashed: HALOE altitude adjusted for bias; Red: variability after removal of horizontal transport.

where increasing differences with $\mathrm{SAOZ}$, as well as decreasing precision, were reported.

\subsubsection{HALOE data selection}

The data in use here are those of version 19 of the retrieval algorithm available on the HALOE website http://haloedata. larc.nasa.gov/. The data selected are a series of measurements on 15 consecutive orbits during or as close as possible to the balloon flight period within the latitudinal range 15$21^{\circ} \mathrm{S}$. The closest available in 2004 are 15 sunrise profiles within $14.9-20.9^{\circ} \mathrm{S}$ on 11-12 February before the launch of the balloon on 26 February. There is no sunset measurement available during the flight period nor sunrise profiles in March within $15-21^{\circ} \mathrm{S}$. The HALOE products available in the data files are ozone mixing ratios on altitude levels. Since the SAOZ measured quantity is a number density, the HALOE mixing ratios data have been converted in concentrations using NCEP (National Center for Environmental Prediction) pressure and temperature also provided in the data files. Finally, since the HALOE vertical resolution is close to that of SAOZ and provided every $300 \mathrm{~m}$, the data have been just linearly interpolated to the SAOZ $1 \mathrm{~km}$ altitude grid.

\subsubsection{Comparison with SAOZ}

The comparisons between HALOE and SAOZ ozone mean profiles, difference, and relative variability, are displayed in Fig. 6 and the results of the analysis for the stratosphere between 22 and $26 \mathrm{~km}$ are summarised in Table 3. Above $22 \mathrm{~km}$, the HALOE mean profile shows a small altitude shift up by $200 \mathrm{~m}$ and a limited ozone high bias of $1.8 \%$ after adjustment for the altitude shift. After removing the contribution of horizontal transport by correlation with PV, the residual variability or precision (in red in the plots) is $3.4 \%$ between 22 and $26 \mathrm{~km}$, which is slightly larger than the $1.5 \%$ of SAOZ. However, as in 2001 and 2003, the difference between HALOE and SAOZ increases rapidly below $22 \mathrm{~km}$ 
Table 3. Difference between HALOE and SAOZ in 2004 between 22 and $26 \mathrm{~km}$ before and after altitude adjustment, and relative variability before / after removal of horizontal transport.

\begin{tabular}{cccccc}
\hline & Diff \% & Alt. bias (m) & Diff\% Alt. adj. & Var SAOZ \% & Var Haloe \% \\
\hline 2004 SR & $3.7 \pm 1.9$ & +200 & $1.8 \pm 1.6$ & $2.2 / 1.5$ & $4.7 / 3.4$ \\
\hline
\end{tabular}

Table 4. Difference in ozone number density or altitude registration between HALOE and SAOZ below $22 \mathrm{~km}$ in 2004, after adjustment for the HALOE altitude shift up by $200 \mathrm{~m}$ above $22 \mathrm{~km}$.

\begin{tabular}{ccc}
\hline Alt. $(\mathrm{km})$ & $\Delta \mathrm{O}_{3}(\%)$ & $\Delta$ Alt. $(\mathrm{m})$ \\
\hline 22 & -0.5 & 0 \\
21 & -11 & 450 \\
20 & -25 & 800 \\
19 & -38 & 1100 \\
18 & -41 & 1550 \\
\hline
\end{tabular}

reaching $1550 \mathrm{~m}$ in altitude or $41 \%$ in number density at $18 \mathrm{~km}$ (Table 4), below which the HALOE data appear not to be reliable.

The comparison with SAOZ in 2004 fully confirms the results of 2001 and 2003. The altitude shift up by $100-200 \mathrm{~m}$ in the lower stratosphere is a well-known feature of HALOE (SPARC, 1998), thought to be due to a bias in the detection of the top edge of the sun in the presence of heavy aerosol or cirrus clouds, particularly in the tropics. The $1.8 \pm 1.6 \%$ ozone high bias between 22 and $26 \mathrm{~km}$ is comparable to the $+1 /-0.7 \%$ difference observed in 2001/2003 at both sunrise and sunset. Finally, the increasing difference between the two systems below $22 \mathrm{~km}$ is very similar on the three years. These results are very consistent with the small bias $(<4 \%)$ between HALOE v19 and SAGE II v6.00 through most of the stratosphere, but increasing systematically (HALOE low compared to SAGE II) below $22 \mathrm{~km}$ as reported by Morris et al. (2002), but for which no satisfactory explanation was provided. The only piece of information we could add here is that it that the increasing difference below $22 \mathrm{~km}$ is to be attribute to HALOE since nothing similar could be seen between SAOZ and all other systems, including SAGE II v6.0, as described in the following sections. However, the still open question is to know if it is resulting from an underestimation of the ozone mixing ratio or a progressively growing error in the HALOE altitude registration.

\subsection{SAGE II}

The Stratospheric Aerosols and Gas Experiment II (SAGE II) aboard the Earth Radiation Budget Satellite (ERBS) launched in October 1984 and still operational in 2004, utilizes the solar occultation method to retrieve ozone, water vapour, aerosols and $\mathrm{NO}_{2}$ (Mauldin et al., 1985). ERBS orbits the Earth along a circular path at an altitude of $610 \mathrm{~km}$ with an inclination of $56^{\circ}$ allowing the measurement of 15 sunset or sunrise profiles every month at a given tropical latitude. Ozone is retrieved in a channel centred at $600 \mathrm{~nm}$ in the Chappuis bands (Cunnold et al., 1989) using cross-sections of Shettle and Anderson (1994). The vertical resolution is $\sim 1 \mathrm{~km}$ and the altitude sampling $0.5 \mathrm{~km}$. Tangent heights are calculated by a solar edge detection algorithm. The precision of the ozone measurements is estimated to $1 \%$ in the middle stratosphere ( $2.5 \%$ accuracy), degrading to about $2 \%$ near the stratopause and the tropopause and to higher values in regions of very low ozone (Manney et al., 2001).

A first comparison between SAGE II v6.2 and SAOZ in 2001 and 2003 at the Southern Tropics at $20^{\circ} \pm 5^{\circ} \mathrm{S}$ during the SH summer (Borchi et al., 2005) showed a relative ozone high bias of $2-4 \%$ in the stratosphere between 20 and $26 \mathrm{~km}$, a small altitude shift up by $100-200 \mathrm{~m}$ and a $2 \%$ precision. In the troposphere, the comparison showed a systematic $50-60 \%$ low bias of SAGE II with a precision of about 40$60 \%$, very consistent with that found between SAGE II and ozonesondes by Kar et al. (2002) and Wang et al. (2002), attributed by these authors to the high sensitivity of the retrieved ozone abundance to the background (electronic offset) of the SAGE II channel.

\subsubsection{SAGE II data selection}

The data in use here are those of version 6.2 of the retrieval algorithm available on the SAGE website www-sage2.larc. nasa.gov. Eleven SAGE II sunset profiles within 15.4$19.7^{\circ} \mathrm{S}$ on $20-21$ March 2004 are available for comparison with SAOZ. There is no sunrise measurement during the balloon flight period. Since the SAGE II products are number densities at geometric altitude on a vertical resolution closed to that of SAOZ and a $500 \mathrm{~m}$ altitude sampling, they have been compared directly to SAOZ by just selecting the data at the $1 \mathrm{~km}$ SAOZ grid.

\subsubsection{Comparison with SAOZ}

The comparison between SAGE II and SAOZ in 2004 is displayed in Fig. 7 in the same format as for HALOE and the results are summarised in Table 5. The SAGE II mean profile shows a small altitude shift up by $150 \mathrm{~m}$ and an ozone high bias of $4.5 \%$ in the stratosphere after adjustment for the 
Table 5. Same as Table 3 for SAGE II and SAOZ, between 20 and $26 \mathrm{~km}$.

\begin{tabular}{cccccc}
\hline & Diff \% & Alt. bias (m) & Diff\% Alt. adj. & Var SAOZ \% & Var SAGE \% \\
\hline 2004 SS & $5.3 \pm 4.3$ & +150 & $4.5 \pm 2.3$ & $3.2 / 1.6$ & $4.7 / 2.5$ \\
\hline
\end{tabular}

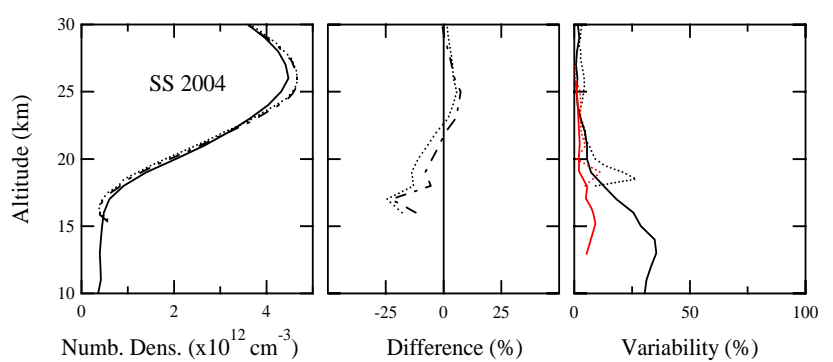

Fig. 7. Same as Fig. 6 but for SAGE II in 2004 at sunset (dotted), altitude adjusted (dotted-dashed) and SAOZ (solid).

altitude shift. Above $20 \mathrm{~km}$, the $2.5 \%$ precision of SAGE II estimated from the variability after subtracting the contribution of transport is of the same order of the $1.6 \%$ found for SAOZ. Unfortunately, only one profile is available between 15.5 and $18 \mathrm{~km}$, thus nothing could be said in 2004 on SAGE II performance in the troposphere.

These findings fully confirm previous SAGE II performances estimations. The altitude shift up by $100-150 \mathrm{~m}$ in the lower stratosphere is a well-known feature of SAGE II, thought to be due to a bias in the solar edge detection algorithm in the presence of a strong gradient in the $1020 \mathrm{~nm}$ extinction profile (SPARC, 1998). The small SAGE ozone high bias is consistent with the $2 \%$ smaller absorption crosssections in use in the SAGE retrieval compared to that of SAOZ (Bazureau, 2001). Finally, the comparable precision of the SAGE broadband channels and the SAOZ spectral measurements suggests that aerosol and Rayleigh attenuations are efficiently removed in the SAGE v6.2 retrieval algorithm.

\subsection{SAGE III moon occultation}

The Stratospheric Aerosol and Gas Experiment III (SAGE III) was launched into a sun-synchronous orbit aboard the Russian Meteor 3M platform in December 2001 (McCormick et al., 1991). SAGE III adds solar and lunar occultation and limb modes. Lunar occultation, the only one available in the tropics, provides profiles of ozone, nitrogen dioxide, nitrogen trioxide, and chlorine dioxide. The hardware configuration of the SAGE III instrument is significantly different from either SAGE I or SAGE II. SAGE III, a grating spectrometer measuring ultraviolet, visible and near infrared radiances from 280 to $1040 \mathrm{~nm}$, builds on and improves on the previous experiments by including additional
Table 6. SAGE III moon occultation selected profiles.

\begin{tabular}{cccc}
\hline Date & Total & Latitude $^{\circ} \mathrm{S}$ & Longitude $^{\circ} \mathrm{E}$ \\
\hline 13 March 2004 & 2 & 19.0 and 24.4 & 110.6 and 56.5 \\
11 April 2004 & 2 & 18.5 and 24.1 & 99.3 and 45.2 \\
\hline
\end{tabular}

wavelength, allowing better $\mathrm{O}_{3}$ measurements at lower altitude (Thomason et al., 1999). Because of the spatial and spectral non-uniformity of the lunar albedo, the variation in lunar illumination as a function of lunar phase, and the moon's relatively low brightness, the lunar altitude registration is much more difficult than that of the sun (SAGE III ATBD, 2002). Tangent heights are derived using a radiometric model of the moon for predicting the radiometric center different from the geometric center in the case of the moon. Below $50 \mathrm{~km}$, ozone is retrieved in the Chappuis bands using cross-sections of Shettle and Anderson (1994). The precision of $\mathrm{O}_{3}$ profiles in lunar occultation mode is about $10 \%$ between 16 and $35 \mathrm{~km}$. The vertical resolution is $500 \mathrm{~m}$. More details could be found in the SAGE III Algorithm Theoretical Basis Document: Solar and Lunar Algorithm (2002).

\subsubsection{SAGE III moon data selection}

The data in use here are those of version 3 of the retrieval algorithm available on the SAGE III website www-sage3. larc.nasa.gov. Four profiles could be found in 2004 close to the latitude and time of the SAOZ flights (Table 6). No collocated data were available for 2003. Since the SAGE III products are ozone number densities at geometric height of $500 \mathrm{~m}$ resolution every $500 \mathrm{~m}$, they have been smoothed and linearly interpolated to the SAOZ $1 \mathrm{~km}$ grid.

\subsubsection{Comparison with SAOZ}

The comparison between SAGE III and SAOZ is displayed in Fig. 8 and the results in Table 7. The SAGE III mean profile shows a large shift down by $550 \mathrm{~m}$, but after adjustment for this altitude shift the ozone bias in the stratosphere drops to $2.5 \%$. Above $20 \mathrm{~km}$ and without removing the contribution of horizontal transport (only four selected profiles), the variability of the concentration is $4.5 \%$ suggesting a precision of the same order of that of SAGE II. But remarkably and in contrast to SAGE II, the bias and precision hold down to the lowest altitude of the measurements at $15 \mathrm{~km}$. 
Table 7. Same as Table 3 for SAGE III moon occultation and SAOZ between 20 and $26 \mathrm{~km}$.

\begin{tabular}{cccccc}
\hline & Diff\% & Alt. bias (m) & Diff\% Alt. adj. & Var SAOZ \% & Var SAGE \% \\
\hline 2004 & $16.3 \pm 5.3$ & -550 & $2.3 \pm 2.0$ & 3.2 & 4.4 \\
\hline
\end{tabular}

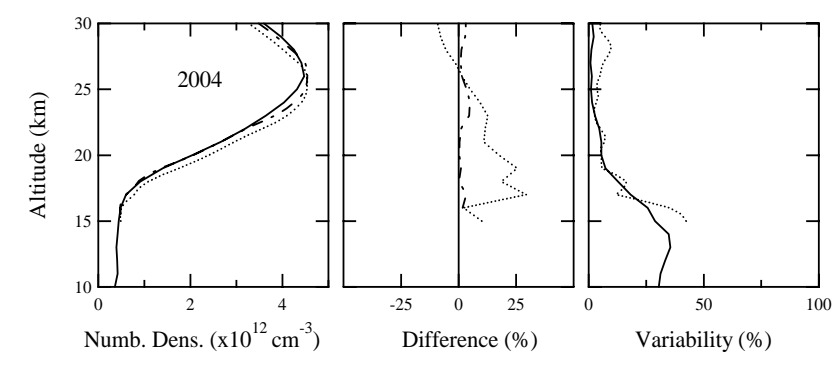

Fig. 8. Same as Fig. 6 but for SAGE III moon occultation (only four collocated profiles) in 2004 (dotted), altitude adjusted (dotteddashed) and SAOZ (solid). The limited number of profiles available does not allow reliable removal of horizontal transport.

Likely because of the larger uncertainty of the lunar altitude registration compared to the sun, the SAGE III altitude bias is larger than that of SAGE II. However, the small ozone high bias is similar to that observed between SAGE II and SAOZ, consistent with the $2 \%$ smaller absorption crosssections in use in both retrievals compared to that of SAOZ (Bazureau, 2001). Finally, the variability of $4.5 \%$ derived from this study, close to that of SAOZ, is slightly better than the $10 \%$ estimated by the SAGE III ATBD (2002), although the small number of profiles available for comparison do not allow definite conclusions on this aspect.

\subsection{Odin-OSIRIS}

The Swedish/Canadian/French/Finish Odin satellite was launched on February 20, 2001 into a circular quasi-polar orbit at $600 \mathrm{~km}$. Detailed information on Odin and its mission can be found in Murtagh et al. (2002) and Llewellyn et al. (2003). Odin carries two co-aligned instruments: a Sub-Millimeter Radiometer (SMR) and an Optical Spectrograph and Infrared Imager System (OSIRIS), both enable to scan the Earth's limb with tangent heights ranging from about 10 to $70 \mathrm{~km}$. The OSIRIS spectrograph measures scattered sunlight within a field of view of $1.288 \mathrm{arc} \min$ in the vertical direction, equivalent to $\sim 1 \mathrm{~km}$ height at the tangent point. Ozone number density profiles are retrieved from the OSIRIS limb radiance spectra in the Chappuis absorption bands between 10 and $50 \mathrm{~km}$ on a $2 \mathrm{~km}$ grid, using the inversion technique suggested by Flittner et al. (2000) and McPeter et al. (2000) and adapted to OSIRIS by von Savigny et al. (2003). The vertical resolution is $2 \mathrm{~km}$. The absorption cross-sections are those of Burrows et al. (1999). Tangent heights are calculated from the viewing direction provided by a star tracker and the orbitography of the satellite. The overall accuracy of an individual profile is estimated to be better than $10 \%$ within the 15 to $35 \mathrm{~km}$ altitude range (von Savigny et al., 2003).

Comparison with 1220 POAM III profiles and 205 ozonesondes (with a much broader latitudinal range in the both Hemisphere) during the 12 month period from November 2001 to October 2002 showed an ozone high bias ranging from 5-7\% for altitudes between 15 and $32 \mathrm{~km}$ and a strong altitude low bias of about $1 \mathrm{~km}$ during the April-July period for which no clear explanation has been provided yet (Petelina et al., 2004). The random error of $100-300 \mathrm{~m}$ at the tangent point was found too small for accounting alone for the offset. The cause was suggested to be presumably due to other altitude registration issues such as misalignment or shift of the optical axis of the instrument in respect to the star-tracker, although it is also possible that systematic errors within the current operational inversion algorithm, such as aerosol climatology, are adding to the problem (Petelina et al., 2004).

\subsubsection{Odin-OSIRIS data selection}

The data in use here are those of version 2.3 of the retrieval algorithm available on the OSIRIS website http:// osirus.usask.ca. Since the MIR travelled only over the Pacific in 2003, a sub-set of data has been built from orbits between $45^{\circ} \mathrm{W}$ and $150^{\circ} \mathrm{E}$. Forty-six OSIRIS profiles within 19.6$24.5^{\circ} \mathrm{S}$ between 15 February and 6 March are available for comparison with SAOZ in 2003 and 42 within $15.0-20.9^{\circ} \mathrm{S}$ between 22 February and 16 March 2004. Since OSIRIS products are number densities every $\mathrm{km}$ geometric height with a resolution close to that of SAOZ, the data have been just interpolated at the $\mathrm{SAOZ} 1 \mathrm{~km}$ grid.

\subsubsection{Comparison with $\mathrm{SAOZ}$}

The comparison between OSIRIS and SAOZ in 2003 and 2004 is shown in Fig. 9 and the results summarised in Table 8 . The OSIRIS mean profiles display an average altitude shift down by $300 \mathrm{~m}$ in 2003 over the Pacific and by $900 \mathrm{~m}$ in 2004 over the entire latitude band. After adjustment for this shift, OSIRIS is found insignificantly high biased compared to SAOZ by $1-2 \%$ in the whole stratosphere down to $19 \mathrm{~km}$ in 2003 and $15 \mathrm{~km}$ in 2004 . The precision above $20 \mathrm{~km}$ estimated from the variability after correction for horizontal transport is $7.4 \%$ in 2003 and $4.7 \%$ in 2004, about 3 times 
Table 8. Same as Table 3 for OSIRIS- SAOZ between 20 and $26 \mathrm{~km}$.

\begin{tabular}{cccccc}
\hline & Diff. \% & Alt. bias (m) & Diff\% Alt. adj. & Var SAOZ \% & Var Osiris \% \\
\hline 2003 & $4.5 \pm 3.3$ & -300 & $1.0 \pm 0.7$ & $4.2 / 2.5$ & $11.3 / 7.4$ \\
2004 & $15.9 \pm 13.1$ & -900 & $2.0 \pm 1.8$ & $3.2 / 1.6$ & $7.2 / 4.7$ \\
\hline
\end{tabular}

worse than that SAOZ. But it degrades progressively below reaching $35 \%$ and $20 \%$ at $15 \mathrm{~km}$ respectively in 2003 and 2004. An important question is the weight in the results of the a priori profile used in the inversion at low altitude. According to von Savigny et al. (2003), the retrieved concentrations should be quite insensitive to the a priori down to $18 \mathrm{~km}$ at low latitude. Overall, the results of the comparison with SAOZ are very consistent with previous evaluations of OSIRIS performances showing a relatively large low bias in altitude registration of unknown origin, but after adjustment for that, a very small 1-2\% ozone bias compared to SAOZ, corresponding exactly to the difference of absorption cross sections (Orphal et al., 2003). The 5\% OSIRIS-ozonesondes mean difference in the $20-26 \mathrm{~km}$ altitude range derived from this study is very consistent with the 5-7\% bias found by Petelina et al. (2004), both after OSIRIS altitude adjustment. The sum of the $1-2 \%$ systematic error and the 5-7\% precision derived from the variability corrected for transport is even better than the $10 \%$ accuracy on individual profiles quoted by von Savigny et al. (2003). The only limitation is the increasing systematic errors in the upper troposphere due to the sensitivity of the retrievals to the a priori profiles. The information provided by the OSIRIS data degrades rapidly below $18 \mathrm{~km}$ in the tropics.

\subsection{Odin-SMR}

The Sub-Millimetre Radiometer (SMR) also aboard Odin employs 4 tuneable single-sideband Schottky-diode heterodyne receivers in the $485-580 \mathrm{GHz}$ spectral range. In aeronomy mode, various target bands are dedicated to observations of trace constituents relevant to stratospheric/mesospheric chemistry and dynamics such as $\mathrm{O}_{3}, \mathrm{ClO}, \mathrm{N}_{2} \mathrm{O}, \mathrm{HNO}_{3}, \mathrm{H}_{2} \mathrm{O}$, $\mathrm{CO}$, and isotopes of $\mathrm{H}_{2} \mathrm{O}$ and $\mathrm{O}_{3}$ (Murtagh et al., 2002). Profile information is retrieved from the spectral measurements of a limb-scan by inverting the radiative transfer equation for a non-scattering atmosphere. A retrieval algorithm based on the Optimal Estimation Method (Rodgers, 1976) has been adopted (Urban et al., 2004). In stratospheric mode, the instrument scans the limb between roughly 7 and $70 \mathrm{~km}$ in about $90 \mathrm{~s}$. Tangent-heights are calculated from the satellite's orbitography and the information of the star tracker. The altitude range of the ozone measurements in the $501.8 \mathrm{GHz}$ band used here is $17-45 \mathrm{~km}$ with vertical resolution of about $2.5 \mathrm{~km}$. The data are provided every $2 \mathrm{~km}$. The precision for a single-scan is of the order of 20-25\% (0.25-1.5 ppmv). The

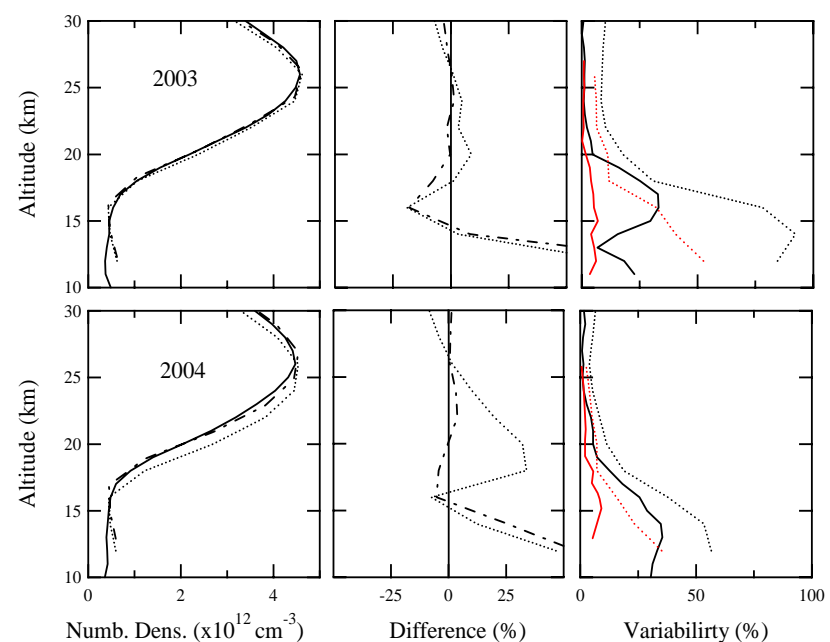

Fig. 9. Same as Fig. 6 but for OSIRIS (dotted), altitude adjusted (dotted-dashed) and SAOZ (solid).

upper limit of systematic errors for $\mathrm{O}_{3}$ in the lower stratosphere is estimated to $\sim 1$ ppmv (Urban et al., 2005).

The two comparisons available between SMR and independent data such as ozonesondes and MIPAS at different periods and locations showed a high $\mathrm{O}_{3}$ bias smaller than $10 \%$ between 20 and $55 \mathrm{~km}$ (Murtagh et al., 2002; Kerridge et al., 2004).

\subsubsection{Odin-SMR data selection}

The data in use here are those of version 222 of the retrieval algorithm available on the SMR website http://ether. ipsl.jussieu.fr. Thirteen SMR profiles within $15.2-26.4^{\circ} \mathrm{S}$ and $45^{\circ} \mathrm{W}-150^{\circ} \mathrm{E}$ (over the Pacific) are available on 18 February 2003 which could be compared to SAOZ and 189 at all longitudes within $15.3-20.7^{\circ} \mathrm{S}$ between 22 February and 20 March 2004. The SMR products available in the data files are ozone-mixing ratios at altitude levels. Since the SAOZ measured quantity is a number density, the SMR data have been converted using ECMWF (European Centre for Medium-Range Weather Forecasts) average pressure and temperature at the SAOZ tangent locations. As the SMR vertical resolution is of $2.5 \mathrm{~km}$ the SAOZ data have been smoothed and then compared to that of SMR on a $2 \mathrm{~km}$ grid. 
Table 9. Same as Table 3 for SMR-SAOZ between 20 and $26 \mathrm{~km}$.

\begin{tabular}{cccccc}
\hline & Diff \% & Alt. bias (m) & Diff\% Alt. adj. & Var SAOZ \% & Var SMR \% \\
\hline 2003 & $6.3 \pm 6.3$ & -350 & $4.3 \pm 4.5$ & $4.2 / 2.5$ & $24.8 / 18.2$ \\
2004 & $8.0 \pm 1.9$ & +300 & $6.7 \pm 5.7$ & $3.2 / 1.6$ & $21.9 / 15.5$ \\
\hline
\end{tabular}

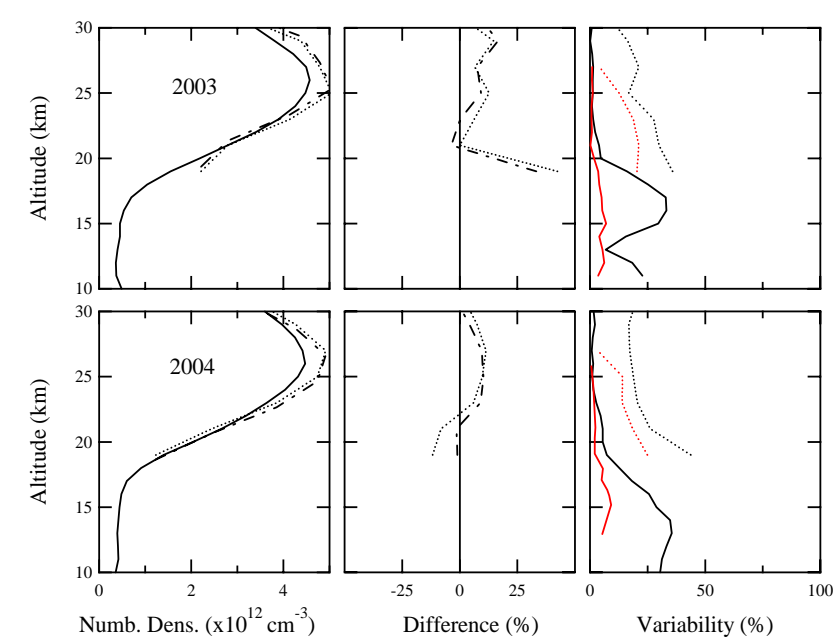

Fig. 10. Same as Fig. 6 but for SMR (dotted), altitude adjusted (dotted-dashed) and SAOZ (solid).

\subsubsection{Comparison with SAOZ}

The comparisons between SMR and SAOZ in 2003 and 2004 are shown in Fig. 10 and the results summarised in Table 9. The SMR mean profiles display an average altitude shift down by $350 \mathrm{~m}$ in 2003 over the Pacific and up by $300 \mathrm{~m}$ in 2004 over the entire latitude band. After adjustment for this shift, the SMR ozone is found high biased compared to SAOZ by $4.3 \%$ in 2003 (with only 13 profiles) and $6.7 \%$ in 2004 (with 189 profiles) between 20 and $26 \mathrm{~km}$. The precision above $20 \mathrm{~km}$ estimated from the variability is $18.2 \%$ in 2003 and $15.5 \%$ in 2004, about 8 times worse than that of SAOZ.

According to Urban et al. (2005), the altitude shift could be resulting from a scan-bias assuming an uncertainty of $500 \mathrm{~m}$. The 9\% SMR high bias compared to the sondes is consistent with the $10 \%$ reported by Murtagh et al. (2002). The precision of $16-17 \%$ derived from this study is slightly better than the 20-25\% estimated by Urban et al. (2005). An important question here also is the weight of the a priori profiles used in the inversion at low altitude. According to Urban et al. (2004) and Urban et al. (2005) retrieved concentrations should be quite insensitive to the a priori down to $19 \mathrm{~km}$ at low latitude. The SMR measurements should have thus little meaning below $19 \mathrm{~km}$ in the tropics.

\subsection{ENVISAT-GOMOS}

The Global Ozone Monitoring by Occultation of Stars (GOMOS) instrument aboard the ENVIronmental SATellite (ENVISAT) has been launched by the European Space Agency on 1 March 2002. ENVISAT is a sun-synchronous polarorbiting satellite at about $800 \mathrm{~km}$ altitude. GOMOS is a star occultation UV-visible-near IR spectrometer providing $\mathrm{O}_{3}$, $\mathrm{NO}_{2}, \mathrm{NO}_{3}, \mathrm{H}_{2} \mathrm{O}$, aerosols and stratospheric clouds measurements, from 15 to $100 \mathrm{~km}$ for $\mathrm{O}_{3}$ and from 20 to $50-60 \mathrm{~km}$ for other constituents (Bertaux et al., 1991; Bertaux et al., 2001). Slant columns of all species are retrieved simultaneously by global minimization of the mean squares difference between measured and modelled transmissions. Below $40 \mathrm{~km}$, ozone is retrieved in the Chappuis bands using crosssections of Burrows et al. (1999). Tangent heights are calculated from the orbitography of the satellite. Since the light source is punctual and the location of the satellite and thus the direction of the star are very accurately known, the altitude registration of the measurements is better than $\pm 50 \mathrm{~m}$. Vertical profiles are derived using an onion peeling inversion technique (Connor and Rodgers, 1988) assuming a linear variation of concentration between 2 layers. A Tikhonov regularization is further applied during the profile inversion for smoothing out unphysical oscillations that can appear on the vertical profiles due to atmospheric scintillation. The smoothing results in a degradation of the vertical resolution to $3 \mathrm{~km}$. The vertical sampling is about $400-500 \mathrm{~m}$. The data used in the following are those produced by a research retrieval algorithm (version v6.0b). Only nighttime measurements are considered.

Comparisons with balloon and ground-based measurements in the 19-64 km altitude range carried with the version $\mathrm{v} 5.4 \mathrm{~b}$ of the algorithm have suggested a small negative bias of $2.5-7.5 \%$, within a relative standard deviation of $11-16 \%$ (Meijer et al., 2004). Compared to SAGE II, the products of v6.0 have shown to display also a small negative bias of 0-5\% between 21 and $52 \mathrm{~km}$ (Bracher et al., 2004).

\subsubsection{ENVISAT-GOMOS data selection}

Fifteen GOMOS profiles within $18.4-25.1^{\circ} \mathrm{S}$ and $45^{\circ} \mathrm{W}-$ $150^{\circ} \mathrm{E}$ (over the Pacific) between 26 February and 4 March in 2003 are available for comparison with $\mathrm{SAOZ}$ and 35 within $14.9-21.0^{\circ} \mathrm{S}$ between 22 February and 20 March 2004. Since the GOMOS products are number densities at 
Table 10. Same as Table 3 for GOMOS-SAOZ between 22 and $26 \mathrm{~km}$.

\begin{tabular}{cccccc}
\hline & Diff \% & Alt bias (m) & Diff\% Alt. adj. & Var SAOZ \% & Var GOMOS \% \\
\hline 2003 & $-2.5 \pm 0.5$ & 0 & NA & $2.1 / 1.1$ & $4.5 / 3.1$ \\
2004 & $-1.1 \pm 0.8$ & -50 & $-1.0 \pm 0.6$ & $2.2 / 1.5$ & $8.9 / 6.1$ \\
\hline
\end{tabular}

geometric height, they can be compared directly to SAOZ. As the GOMOS vertical resolution is $3 \mathrm{~km}$ and the sampling $400-500 \mathrm{~m}$, the SAOZ data have been smoothed and those of GOMOS linearly interpolated to the SAOZ altitude grid of $1 \mathrm{~km}$.

\subsubsection{Comparison with SAOZ}

The comparisons between GOMOS and SAOZ in 2003 and 2004 are displayed in Fig. 11 and the results summarised in Table 10. On both years, the mean profiles of the two instruments are very consistent above $22 \mathrm{~km}$ in the stratosphere showing no altitude shift within $\pm 50 \mathrm{~m}$ and a small, little significant, low ozone bias of GOMOS of $1-2.5 \%$. At these altitude levels, the only difference is in the worse precision of GOMOS of $3.1 \%$ over the Pacific in 2003 and $6.1 \%$ over the full latitude band in 2004 above $22 \mathrm{~km}$, but degrading very rapidly below that level.

The absence of altitude shift between GOMOS and SAOZ is very consistent with the expectation of a star occultation system. The small low ozone bias is fully corresponding to the difference of $2.5 \%$ between ozone absorption crosssections used respectively by the two algorithms in the visible Chappuis bands (Orphal et al., 2003). The 1\% GOMOS low bias compared to SAGE II is also consistent with the 0-5\% reported by Bracher el al. (2004), both after altitude adjustment. The main limitation of GOMOS ozone measurements demonstrated by the comparison is the relatively large random error on individual profiles of $\sim 6 \%$ (one standard deviation) in the stratosphere above $22 \mathrm{~km}$ related to chromatic scintillation due to small-scale atmospheric turbulence structures. Finally, because of the fast increase of noise below $22 \mathrm{~km}$, current GOMOS ozone products are of little use in the Tropical Tropopause Layer (TTL) and in the troposphere.

\subsection{ENVISAT-SCIAMACHY}

SCIAMACHY (SCanning Imaging Absorption spectroMeter for Atmospheric CHartographY) is a satellite-borne instrument also aboard ENVISAT capable of performing spectroscopic measurements of the chemical composition of the Earth's atmosphere in three different observation geometries: nadir, solar/lunar occultation and limb scattering (Burrows and Chance, 1991; Bovensmann et al., 1999). The O 3 limb profiles used here are derived by the Institute of Environmental Physics at University of Bremen (IUP). The retrieval al-

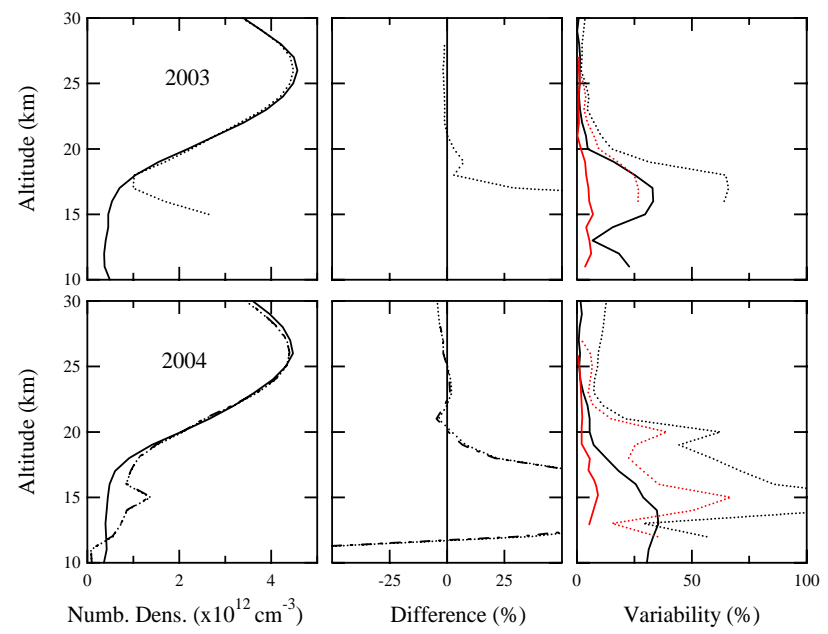

Fig. 11. Same as Fig. 6 but for GOMOS (dotted), altitude adjusted (dotted-dashed) and SAOZ (solid).

gorithm employed is similar to that developed by Flittner et al. (2000) and McPeters et al. (2000) for the Shuttle Ozone Limb Sounding Experiment (SOLSE) also used for OSIRIS (von Savigny et al., 2003). The retrieval exploits the differential structure of the $\mathrm{O}_{3}$ absorption cross sections, measured in the laboratory with the SCIAMACHY Flight Model, between the centre $(600 \mathrm{~nm})$ and the wings $(525 \mathrm{~nm}$ and $675 \mathrm{~nm}$ ) of the Chappuis absorption bands. A linearised version of optimal estimation is used together with the radiative transfer model SCIARAYS (Kaiser, 2001) to iteratively retrieve stratospheric $\mathrm{O}_{3}$ concentration profiles. The altitude range from about $15 \mathrm{~km}$ up to $40 \mathrm{~km}$ with vertical a resolution of about $3.5-4.0 \mathrm{~km}$ can be covered with this technique as long as there are no clouds or aerosols in the instrument's field of view. The data are provided every $1 \mathrm{~km}$ in the altitude range $10-50 \mathrm{~km}$. Tangent heights are calculated from the viewing direction provided by a star tracker and the orbitography of the satellite. The instrumental error is smaller than $1 \%$, but retrieval errors due to errors in the assumptions of albedo, aerosol profile and background atmosphere are generally larger. Sensitivity studies have shown that these are the major systematic error sources and vary between $6 \%$ and $10 \%$ at $15-40 \mathrm{~km}$ altitude and around $6-7 \%$ between 20 and $25 \mathrm{~km}$ (Rozanov et al., 2003).

The SCIAMACHY v1.6 ozone profiles have been shown to be low biased by $10-15 \%$ for an unknown reason in the 
Table 11. Same as Table 3 for SCIAMACHY-SAOZ between 20 and $26 \mathrm{~km}$.

\begin{tabular}{cccccc}
\hline & Diff \% & Alt. bias (m) & Diff\% Alt. adj. & Var SAOZ \% & Var SCIA \% \\
\hline 2003 & $-1.4 \pm 4.5$ & +250 & $2.1 \pm 1.5$ & $4.2 / 2.5$ & $7.7 / 5.2$ \\
2004 & $7.2 \pm 3.7$ & -300 & $5.5 \pm 2.5$ & $3.2 / 1.6$ & $5.4 / 3.7$ \\
\hline
\end{tabular}

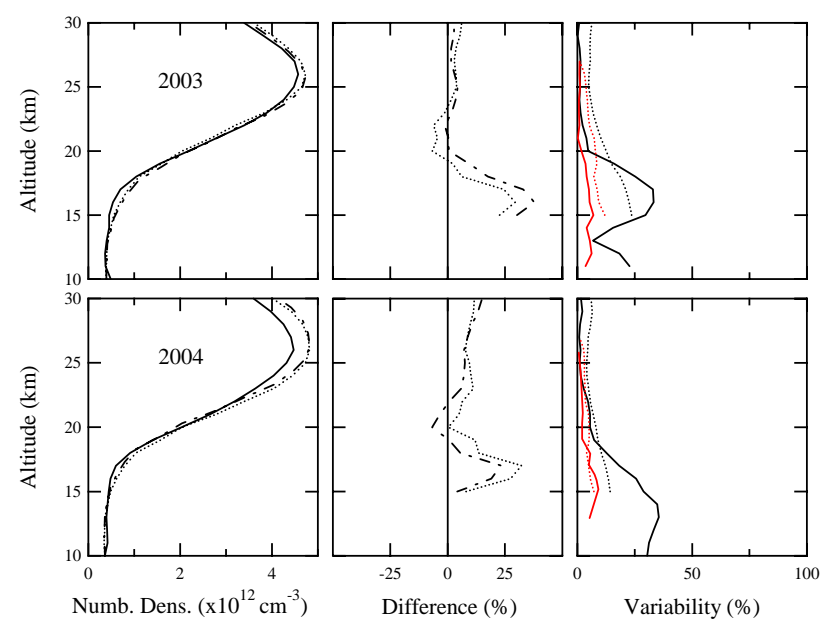

Fig. 12. Same as Fig. 6 but for SCIAMACHY (dotted), altitude adjusted (dotted-dashed) and SAOZ (solid).

altitude range 20-35 km compared to HALOE, SAGE II and III, GOMOS, MIPAS, lidars and sondes, as well as shifted up by 1 to $2 \mathrm{~km}$ compare to all others (Bracher et al., 2005; Brinksma et al., 2005; Rozanov et al., 2003; Segers et al., 2005). The altitude shift was identified to mainly result from pointing errors caused by an incorrect knowledge of the satellite orientation and/or position (Rozanov et al., 2003). A monthly mean tangent height offset of $800 \mathrm{~m}$ amplitude was identified before the improvement of the ENVISAT orbit propagator model in December 2003, but a constant offset component of about $1 \mathrm{~km}$ is still presents after (von Savigny et al., 2005).

\subsubsection{ENVISAT-SCIAMACHY data selection}

The data in use here are those of a new version 1.63 of the retrieval algorithm provided by IUP. Version 1.63 includes the following main changes and improvements compared to version v1.6. First, the retrievals are performed on a $1 \mathrm{~km}$ altitude grid compared to the previously used $3.3 \mathrm{~km}$ altitude grid - corresponding to the tangent height grid - in v1.6. Second, the v1.63 retrievals are corrected for pointing errors using the version 1.7 of the TRUE (Tangent height Retrieval by UV-B Exploitation) algorithm (Kaiser et al., 2004; von Savigny et al., 2005), which employs ECMWF background atmosphere and ozone profiles taken from the dynamic ozone climatology of Lamsal et al. (2004). The ozone profiles are selected from the climatology following the TOMS v8 total ozone column for a given day and location. Forty-three SCIAMACHY profiles within $15.9-24.8^{\circ} \mathrm{S}$ and $45^{\circ} \mathrm{W}-150^{\circ} \mathrm{E}$ (over the Pacific) are available between 18 February and 4 March 2003 for comparison with SAOZ and 65 within $16.2-20.9^{\circ} \mathrm{S}$ on 15 to 29 February 2004. The SCIAMACHY products are number densities at geometric height, which can be therefore compared directly to SAOZ. As the SCIAMACHY vertical resolution is of $3.5-4.0 \mathrm{~km}$ the SAOZ data have been smoothed and then compared to that of SCIAMACHY on a $1 \mathrm{~km}$ grid.

\subsubsection{Comparison with SAOZ}

SCIAMACHY and SAOZ ozone profiles in 2003 and 2004 are shown in Fig. 12 and the results of the analysis summarised in Table 11. The SCIAMACHY mean profiles display an altitude shift up by $250 \mathrm{~m}$ over the Pacific in 2003 and down by $300 \mathrm{~m}$ in 2004 on average over the entire latitude band. After adjustment for this shift, the ozone concentration is found high biased compared to $\mathrm{SAOZ}$ by $5-6 \%$ in the stratosphere between 20 and $26 \mathrm{~km}$, that is $3 \%$ high biased compared to SAGE II. Still above $20 \mathrm{~km}$, the precision estimated from the variability is $5.2 \%$ in 2003 and $3.7 \%$ in 2004, about 2 times worse than that of SAOZ.

The new v1.63 version of the retrieval is encouraging showing significant improvements compared to v1.6. The altitude shift of $\pm 300 \mathrm{~m}$ is significantly reduced compared to the constant offset of about $1 \mathrm{~km}$ found by von Savigny (2005) with the v1.6. The 3\% SCIAMACHY high bias compared to SAGE II is also reduced compared to the $6 \%$ low bias reported by Brinksma et al. (2005). Finally, the precision of $4 \%$ is also better than the error estimate of $6-7 \%$ in the 20-25 km altitude range of Rozanov et al. (2003).

However, little change is observed below $20 \mathrm{~km}$ in the upper troposphere, where the difference with SAOZ increases rapidly (30\% and $25 \%$ at $17 \mathrm{~km}$ respectively in 2003 and 2004). As concluded by Brinksma et al. (2005) and confirmed by the small atmospheric variability compared to that observed by SAOZ, the profiles are strongly weighted by the a priori used in the retrieval. The information provided by SCIAMACHY is thus of no use in the tropical troposphere. 
Table 12. Same as Table 3 for MIPAS-SAOZ between 20 and $26 \mathrm{~km}$.

\begin{tabular}{cccccc}
\hline & Diff $\%$ & Alt. bias (m) & Diff\% Alt. adj. & Var SAOZ \% & Var MIPAS \% \\
\hline 2003 & $3.7 \pm 3.3$ & -350 & $0.6 \pm 0.8$ & $2.1 / 1.0$ & $8.2 / 5.3$ \\
2004 & $7.8 \pm 9.0$ & -300 & $7.1 \pm 3.1$ & $3.2 / 1.6$ & $11.8 / 8.5$ \\
\hline
\end{tabular}

\subsection{ENVISAT-MIPAS}

MIPAS (Michelson Interferometer for Passive Atmospheric Sounding) aboard ENVISAT is a limb-viewing Fourier transform infrared (FTIR) emission spectrometer covering the mid-infrared region in five spectral bands (Fischer and Oelhaf, 1996; Harris, 2000). The data used here (ESA level-2 near real time operational products) are taken in the standard observation mode, which consists in rearward limb scans covering the altitude range from 6 to $68 \mathrm{~km}$ within 17 steps. The vertical resolution is $3 \mathrm{~km}$ for the 13 lowermost tangent altitudes and increases to $8 \mathrm{~km}$ at the upper end of the limb scan. The ozone profiles are derived using an optimized retrieval model (ORM) (Carli et al., 2004; Ridolfi et al., 2000). The vertical sampling is of about $2.3 \mathrm{~km}$. At low latitude, the ozone total error is estimated around $8-10 \%$ at $20-50 \mathrm{~km}$, rapidly increasing below $20 \mathrm{~km}$ to $50-60 \%$ (Dudhia et al., 2002). Between 20 and $25 \mathrm{~km}$, HALOE-MIPAS and SAGE II-MIPAS ozone mean difference shows a low bias of 7-8\% and 4-5\% respectively (Kerridge et al., 2004). MIPAS measurements in 2002 and 2003 indicate a slow drift in instrumental pointing towards lower tangent heights (von Clarmann et al., 2003). Since December 2003, a correction scheme based on both engineering and orbit model updates has been provided by ESA that leads to improved limb pointing. Nevertheless, some residual pointing errors still appear to be present in the data.

\subsubsection{ENVISAT-MIPAS data selection}

The data used here are those of MIPAS NL (the Level 2 near real time operational products) version 4.61 of the retrieval algorithm available on ftp-ops.de.envisat.esa.int. Twelve MIPAS profiles within $17.7-23.3^{\circ} \mathrm{S}$ between 18 February and 7 March 2003 are available for comparison with SAOZ and 441 within $16.9-20.1^{\circ} \mathrm{S}$ between 27 February and 15 March 2004. The data used are volume mixing ratios in pressure coordinate, where the pressure is retrieved from the MIPAS spectra. They have been converted in number density and altitude coordinate using ECMWF pressure and temperature. Indeed, the altitude coordinate also available in the MIPAS data files is not being used since appearing to show significant errors. Although the geometric altitudes are derived from retrieved tangent-pressures, the need to fix the geometric altitude of a reference pressure level introduces the possibility for an offset in absolute heights assigned (Kerridge et

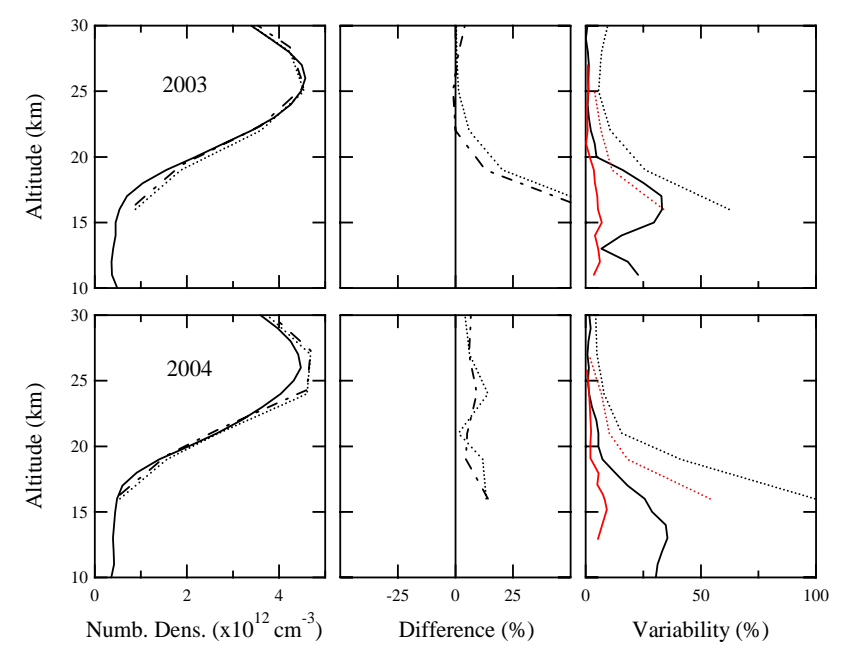

Fig. 13. Same as Fig. 6 but for MIPAS (dotted) in 2003, altitude adjusted (dotted-dashed) and SAOZ (solid).

al., 2004). Since the MIPAS vertical resolution is $3 \mathrm{~km}$ the SAOZ data have been smoothed and linearly interpolated to the MIPAS altitude grid of $\sim 2.3 \mathrm{~km}$ altitude grid.

\subsubsection{Comparison with $\mathrm{SAOZ}$}

The MIPAS and SAOZ profiles in 2003 and 2004 are compared in Fig. 13 and the results summarised in Table 12. The MIPAS mean profiles display an altitude shift down by $350 \mathrm{~m}$ in 2003 over the Pacific and by $300 \mathrm{~m}$ in 2004 over the entire latitude band. After adjustment for this shift, MIPAS is found high biased in the stratosphere between 20 and $26 \mathrm{~km}$ compared to SAOZ by $0.6 \%$ in 2003 and $7.1 \%$ in 2004 , the last established on 441 profiles being more significant than the first based on only 12 profiles. The difference increases below $20 \mathrm{~km}$ reaching $14 \%$ at $16 \mathrm{~km}$ in 2004 . The precision above $20 \mathrm{~km}$ estimated from the variability is $5.3 \%$ in 2003 and $8.5 \%$ in 2004, but decreases below reaching $34 \%$ and $54 \%$ at $16 \mathrm{~km}$ respectively in 2003 and 2004.

Overall the results of the comparison with SAOZ are very consistent with previous evaluations of MIPAS performances. However, the present work does show a systematic altitude shift down by $\sim 300 \mathrm{~m}$ in the tropics in both 2003 and 2004 presumably due to instrumental pointing errors. The $-5 \%$ HALOE-MIPAS and $-7 \%$ SAGE II-MIPAS differences derived from their respective differences with $\mathrm{SAOZ}$ 
Table 13. Summary of performances of all instruments relative to SAOZ in the stratosphere above $20 \mathrm{~km}$, unless stated otherwise, in 2004 (2001).

\begin{tabular}{lllll}
\hline Instrument & Alt. bias $(\mathrm{m})$ & $\mathrm{O}_{3}$ Bias $(\%)$ & Precision $(\%)$ & Remark \\
\hline SAOZ & - & - & $2(2)$ & \\
Ozonesondes & $+200(300)$ & $+1.5(-4)$ & $4(5)$ & \\
HALOE Z $>22 \mathrm{~km}$ & $+200(<+100)$ & $+1.8(<1)$ & $3.4(4)$ & Bias or altitude, and precision degrading below $22 \mathrm{~km}$ \\
SAGE II & $+150(+150)$ & $+2.5(+4.5)$ & $2.5(2)$ & \\
SAGE III moon & -550 & +2.5 & $4.5 *$ & 4 profiles only. * H. transport not removed \\
Odin-OSIRIS & -900 & +2 & 5 & \\
Odin-SMR & +300 & +7 & 16 & Bias and precision degrading below $22 \mathrm{~km}$ \\
GOMOS Z $>22 \mathrm{~km}$ & -50 & -1.5 & 6 & \\
SCIAMACHY & -300 & +5.5 & 4 & \\
MIPAS & -300 & +7 & 8.5 & \\
\hline
\end{tabular}

Table 14. Mean differences between instruments in the $20-26 \mathrm{~km}$ altitude range derived from the present study in 2004 and available from the literature.

\begin{tabular}{lccc}
\hline & Diff $\%$ & Diff in literature $\%$ & Altitude adjusted \\
\hline OSIRIS-Sondes & +5 & $+5 /+7$ & Yes \\
SMR-Sondes & +9 & +10 & Yes \\
GOMOS-SAGE II & -1 & $-5 / 0$ & No \\
SCIAMACHY-SAGE II & +3 & -6 & Yes \\
HALOE-MIPAS & -5 & $-7 /-8$ & No \\
SAGE II-MIPAS & -7 & $-4 /-5$ & No \\
\hline
\end{tabular}

are of the same order of magnitude of the $-7 /-8 \%$ and $-4 /-5 \%$ noted by Kerridge et al. (2004). The precision of $8.5 \%$ above $20 \mathrm{~km}$ in 2004 reported here degrading rapidly below, is comparable with the $8-10 \%$ reported by Dudhia et al. (2002). According to Carli et al. (2004), the retrieved concentrations should be insensitive to the a priori profile used in the inversion down to $16 \mathrm{~km}$ at low latitude. However, the increased high bias and the degradation of precision suggest that the MIPAS ozone profiles are of little use in the Tropical Troposphere Layer.

\section{Summary of performances of ozone measuring in- struments in tropics}

The performances of all available ozone-measuring instruments in the tropical stratosphere relative to SAOZ in 2003 and 2004 are summarized in Table 13. For ozonesondes, HALOE and SAGE II, they fully confirm the conclusions of 2001 (Borchi et al., 2005). A remarkable feature is the frequent errors in altitude registration varying from $+100 /+200 \mathrm{~m}$ for solar occultation systems (SAGE II, HALOE) to shifts as large as $-900 \mathrm{~m}$ for the limb viewing OSIRIS. As expected, the most precise altitude is that of the GOMOS star occultation system whose observing direction is very accurately known since the light source is punctual. As expected also, the ozonesondes are shifted up by 200$300 \mathrm{~m}$ because of their time constant. Curiously, the SAGE III moon occultation instrument, using a moon edge detection algorithm similar to that of the SAGE II solar system, is showing a shift down by $550 \mathrm{~m}$. Another feature, which did not received any explanation yet, is the increasing shift up or ozone low bias of the HALOE profiles below $22 \mathrm{~km}$, as large as $1500 \mathrm{~m}$ (or $40 \%$ in ozone) at $18 \mathrm{~km}$, present at both sunrise and sunset, in 2001, 2003 and 2004 compared to SAOZ, identical to that already reported between SAGE II and HALOE. Since no such difference was found between SAOZ, SAGE II and all other systems, it can be safely attributed to HALOE.

The ozone bias relative to SAOZ is generally small, between $-2 \%$ and $+4 \%$ for most of the instruments performing in the visible Chappuis bands and near IR (SAGE II and III, GOMOS, OSIRIS and HALOE), within their $\pm 5 \%$ accuracy for the ozonesondes, but it increases for SCIAMACHY still in the visible $(+5.5 \%)$, MIPAS in the mid-IR $(+7 \%)$ and SMR in the sub-millimeter region $(+7 \%)$. Most of above biases are not new. On average, as shown in Table 14, the differences between a couple of instruments derived here are very consistent with those of previous evaluations. 
But new here is the evaluation of the precision of each by a statistical method based on the limited ozone variability in the tropical stratosphere, moreover shown to be mainly due to horizontal transport efficiently removed by a regression analysis using potential vorticity (PV) as proxy. Most precise are found to be SAGE II and SAOZ ( 2\%), followed by HALOE (3-4\% above $22 \mathrm{~km}$ ), the sondes, SAGE III moon, OSIRIS and SCIAMACHY (4-5\%), GOMOS above $22 \mathrm{~km}$ $(\sim 6 \%)$, MIPAS $(8.5 \%)$ and finally SMR $(16 \%)$. These figures are more or less consistent with previous precision estimates by other methods, but more importantly they fully agree with known or suspected limitations of instrumental and retrieval techniques.

Tropospheric ozone measurements by remote sensing from space remain a difficult task. There are several reasons for that: the strong signal attenuation by Rayleigh scattering, the masking by clouds, the weakening of IR emission at low temperature, or the increased scintillation because of turbulence, etc. Another concern for limb observing systems using optimisation retrievals is the information effectively carried by the measurements compared to the weight of the a priori climatic profile. Finally, since remote observations are not possible within clouds, there is a risk of systematic overestimation of tropospheric ozone if the concentration is reduced inside the clouds particularly in convective regions. The best instrument for measuring ozone in the troposphere remains ozonesondes. The performances of most satellite instruments degrade rapidly below $20 \mathrm{~km}$ and sometimes $22 \mathrm{~km}$ (HALOE, GOMOS). The only satellite, which may provide some meaningful information in the upper troposphere, is SAGE II (may be SAGE III also) although low biased by $50 \%$ and of limited (50\%) precision.

\section{Conclusions}

A large number of high accuracy ozone profiles has been obtained from 10 to $26 \mathrm{~km}$ in 2001, 2003 and 2004 in the tropical UTLS by solar occultation spectroscopic measurements from long duration balloons carrying a SAOZ UV-Vis spectrometer. As shown by a statistical study, the ozone variability along a latitudinal circle at $\sim 20^{\circ} \mathrm{S}$, is smaller than $5 \%$ in the stratosphere above $19 \mathrm{~km}$ but increases rapidly below in the TTL reaching a maximum of $40 \%$ at $14 \mathrm{~km}$ immediately below the tropopause. In addition, the high correlation between Potential Vorticity and ozone at all levels suggests that most of the variability (60-70\%) could be attributed to horizontal transport and could therefore be efficiently removed from the observed variability by a regression technique. Assuming that other contributions, i.e. photochemistry or convective transport, are negligible, the residual variability after removing horizontal transport provides a rigorous estimation of the precision of the measurements. In the case of SAOZ it is shown that it could vary from $\sim 2 \%$ in the stratosphere,
5-6\% at the tropopause and $7-8 \%$ at $12 \mathrm{~km}$ in the upper troposphere.

Using SAOZ as reference, the relative performances of all ozone-measuring instruments available in the tropics during the period of the balloon flights have been evaluated. It is shown that frequent positive or negative altitude shifts could be observed in the ozone profiles, varying from zero for the GOMOS stellar occultation instrument, followed by $+100 / 200 \mathrm{~m}$ for solar occultation systems (SAGE II, HALOE), but as large as $-900 \mathrm{~m}$ for the limb viewing system OSIRIS. In the case of HALOE, a fast increasing degradation of altitude registration is observed below $22 \mathrm{~km}$. The ozone biases are generally limited, between $-4 \%$ and $+4 \%$, for measurements in the visible Chappuis bands (SAGE II and III, GOMOS and OSIRIS), the near IR (HALOE above $22 \mathrm{~km}$ ) and the ozonesondes, but increases to $+5.5 \%$ (SCIAMACHY) although still in the visible, and 7\% in the mid-IR (MIPAS) and the submillimetric range (ODIN-SMR). Regarding precision, the best measurements are found to be those of SAGE II (2\%), followed by HALOE (3-4\% above $22 \mathrm{~km}$ ), the sondes, SAGE III moon, SCIAMACHY and OSIRIS (4-5\%), GOMOS but only above $22 \mathrm{~km}(\sim 6 \%)$, MIPAS $(8.5 \%)$ and finally SMR (16\%). All satellite measurements appear very little reliable in the tropical troposphere, except those of SAGE II, though low biased by 50\% and of limited (50\%) precision. Finally, it must be recognised that the retrieval algorithms associated to the various systems investigated here are not at same stage of maturity. For most recent instruments, e.g. onboard ENVISAT, the data shown here are frequently those of research versions of the algorithms expected to receive improvements in the near future. It is hoped that this analysis could contribute. The SAOZMIR data remain available for that.

\section{Appendix A}

\section{Mathematical background}

The statistical method is to compare mean zonal profiles indicative of potential relative biases in concentration or altitude registration, mean differences, and relative variability along a latitudinal circle, indicative of measurements precision. The bias in altitude is given by minimizing the mean value of the relative differences between 20 and $26 \mathrm{~km}$.

$\operatorname{Diff}_{i}=100 \frac{\overline{x_{i}}-\overline{\mathrm{SAOZ}_{i}}}{\overline{\mathrm{SAOZ}_{i}}}$

All variables are implicitly altitude dependent. The $i$ index refers to the $i$ th altitude. $\overline{x_{i}}$ is the mean ozone number density of the correlative data and $\overline{\mathrm{SAOZ}_{i}}$ that of SAOZ. Diff ${ }_{i}$ is the relative percent difference.

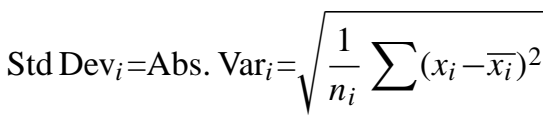


Std $\operatorname{Dev}_{i}$ is the standard deviation, equivalent to the absolute ozone variability Abs. $\operatorname{Var}_{i}$.

Rel. Std $\operatorname{Dev}_{i}=$ Rel. $\operatorname{Var}_{i}=100 \frac{\mathrm{Abs} \operatorname{Var}_{i}}{\overline{\mathrm{SAOZ}_{i}}}$

Rel. Std $\operatorname{Dev}_{i}$ is the relative standard deviation, equivalent to the relative variability $\mathrm{Rel}_{\text {. }} \mathrm{Var}_{i}$.

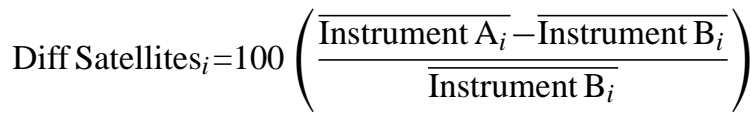

Diff Satellites ${ }_{i}$ is the difference between two instruments, equivalent to the ozone bias.

Acknowledgements. The authors thank the engineers and technicians of the Service d'Aéronomie, A. Garnier the project manager, P. François and E. d'Almeida who built the SAOZ instrument and M. Nunes-Pinharanda for the data processing, the personnel of the Institute of Meteorology (IPMet) of the State University of Sao Paulo (UNESP) and of the Centre National d'Etudes Spatiales (CNES) for the balloon operations. They thank also N. Larsen and J. Nielsen, F. Posny and S. Oltmans for the ozonesondes ascents during the MIR overpasses above Bauru, Reunion Island, Samoa and Fiji. The SAGE II and III, and HALOE data have been provided by the NASA Langley Radiation and Aerosols Branch, those of ENVISAT by ACRI in France (GOMOS), the European Space Agency (MIPAS), those of ODIN by the Observatoire Aquitain des Sciences de l'Univers at Bordeaux (SMR) and the Infrared and Aeronomy Group at the University of Saskatchewan (OSIRIS) who are all acknowledged, especially C. von Savigny and J. Burrows from the Institute of Environmental Physics at the University of Bremen for providing the results of the most recent research retrievals of SCIAMACHY and R. MacKenzie for his corrections which greatly improved the paper. The project was supported by the ENVISAT validation programme ESABC, project 713, the Programme National de Chimie de l'Atmosphère (PNCA) in France and the European Commission within the HIBISCUS project (contract EVK2-2001-000111). They are all gratefully acknowledged.

\section{Edited by: R. MacKenzie}

\section{References}

Bazureau, A.: Préparation de l'inversion des mesures de transmission de l'expérience spatiale SAGE III: mise en place et étude des algorithmes d'inversion, $\mathrm{PhD}$ thesis, Université des Sciences et Technologies de Lille, 2001.

Bertaux, J. L., Megie, G., Widemann, T., Chassefière, E., Pellinen, R., Kyrola, Korpela, S., and Simon, P.: Monitoring of ozone trend by stellar occultations: the GOMOS instrument, Adv. Space Res., 11, 237-242, 1991.

Bertaux, J. L., Dalaudier, F., and Hauchecorne, A.: Envisat, GOMOS-An instrument for global atmosphere ozone monitoring, edited by: Harris R. A., ESA SP-1244, 109 pp., 2001.

Bhatt, P. P., Remsberg, E. E., Gordley, L. L., McInerney, J. M., Bracket, V. G., and Russel III, J. M.: An evaluation of the quality of HALogen Occultation Experiment ozone profiles in the lower stratosphere, J. Geophys. Res., 104, 9261-9275, 1999.
Borchi, F., Pommereau, J.-P., Garnier, A., and Nunes-Pinhanrada, M.: Evaluation of SHADOZ sondes, HALOE and SAGE II ozone profiles at the tropics from SAOZ UV-Vis remote measurements onboard long duration balloons, Atmos. Chem. Phys., 5, 1381-1397, 2005,

http://www.atmos-chem-phys.net/5/1381/2005/.

Bovensmann, H., Burrows, J. P., Buchwitz, M., Frerick, J., Noël, S., and Rozanov, V. V.: SCIAMACHY: Mission objectives and measurement modes, J. Atmos. Sci., 56, 127-150, 1999.

Bracher, A., Bramstedt, K., Richter, A., Sinnhuber, M., Weber, M., and Burrows, J. P.: Validation of SCIAMACHY and GOMOS $\mathrm{O}_{3}$ and $\mathrm{NO}_{2}$ products with GOME, HALOE and SAGE II, in: Proc. Second Workshop on the atmospheric chemistry validation of ENVISAT (ACVE-2), edited by: Danesy, D., ESA SP-562, 2004.

Bracher, A., Bovensmann, H., Bramstedt, K., Burrows, J.P., von Clarmann, T., Eichmann, K.-U., Fischer, H., Funke, B., GilLopez, S., Glatthor, N., Grabowski, U., Höpfner, M., Kaufmann, M., Kellmann, S., Kiefer, M., Koukouli, M.E., Linden, A., Lopez-Puertas, M., Mengistu Tsidu, G., Milz, M., Noel, S., Rohen, G., Rozanov, A., Rozanov, V.V., von Savigny, C., Sinnhuber, M., Skupin, J., Steck, T., Stiller, G.P., Wang, D.-Y., Weber, M., and Wuttke, M. W.: Cross comparisons of $\mathrm{O}_{3}$ and $\mathrm{NO}_{2}$ measured by the atmospheric ENVISAT instruments, GOMOS, MIPAS, and SCIAMACHY, Adv. Space Res., 36, 855-867, 2005.

Brinksma, E. J., Bracher, A., Lolkema, D. E., Segers, A. J., Boyd, I. S., Bramstedt, Claude, H., Godin-Beekmann, S., Hansen, G., Kopp, G., Leblanc, T., McDermid, I. S., Meijer, Y. J., Nakane, H., Parrish, A., von Savigny, C., Stebel, K., Swart, D. P. J., Taha, G., and Piters, A. J. M.: Geophysical validation of SCIAMACHY Limb Ozone Profiles, Atmos. Chem. Phys., 6, 197209, 2006, http://www.atmos-chem-phys.net/6/197/2006/.

Burrows, J. P. and Chance, K. V.: Scanning imaging absorption spectrometer for atmospheric chartography, Proc. Int. Soc. Opt. Eng., 1490, 146-155, 1991.

Burrows, J. P., Richter, A., Dehn, A., Daters, B., Himmelmann, S., Voigt, S., and Orphal, J.: Atmospheric remote-sensing reference data from GOME-2, Temperature dependent absorption cross section of $\mathrm{O}_{3}$ in the 231-794 nm range, J. Quant. Spectr. Radiat. Transfer, 509-517, 1999.

Carli, B., Alpaslan, D., Carlotti, M., Castelli, E., Ceccherini, S., Dinelli, B. M., Dudhia, A., Flaud, J.-M., Hoepfner, M., Jay, V., Magnani, L., Oelhaf, H., Payne, V., Piccolo, C., Prosperi, M., Raspollini, P., Remedios, J., Ridolfi, M., and Spang, R.: First results of MIPAS/ENVISAT with operational Level 2 code, Adv. Space Res., 33, 1012-1019, 2004.

Connor, B. J. and Rodgers, C. D.: A comparison of retrieval methods: Optimal estimation, onion peeling, and a combination of the two, in: Adv. Remote Sensing Retrieval Methods, edited by: Deepak, A., 271-281, 1988.

Cunnold, D., Chu, M., Barnes, W. P., McCormick, R. A., and Veiga, R. E.: Validation of SAGE II ozone measurements, J. Geophys. Res., 94, 8447-8460, 1989.

Dudhia, A., Jay, V. L., and Rodgers, C., D.: Microwindow selection for high-spectral-resolution sounders, Appl. Opt., 41, 36653673, 2002.

Flittner, D. E., Bhartia, P. K., and Herman, B. M.: $\mathrm{O}_{3}$ profiles retrieved from limb scatter measurements: Theory, Geophys. Res. 
Lett., 27, 2601-2604, 2000.

Fischer, H. and Oelhaf, H., Remote sensing of vertical profiles of atmospheric constituents with MIPAS limb-emission spectrometer, Appl. Opt., 35, 2787-2796, 1996.

Funke, B., Lopez-Puertas, M., von Clarmann, T., Stiller, G. P., Fischer, H., Glatthor, N., Grabowski, U., Höpfner, M., Kellmann, S., Kiefer, M., Linden, A., Mengistu Tsidu, G., Milz, M., Steck, T., and Wang, D. Y.: Retrieval of stratospheric NOx from 5.3 to $6.2 \mathrm{~lm}$ non-LTE emissions measured by MIPAS on ENVISAT, J. Geophys. Res., 110, D09302, doi:10.1029/2004JD005225, 2005.

Harris, R. A.: Envisat: MIPAS-An instrument for atmospheric chemistry and climate research, edited by: Harris, R. A., ESA SP-1229, 124 pp., 2000

Hauchecorne, A., Godin, S., Marchand, M., Heese, B., and Souprayen, C.: Quantification of the transport of chemical constituents from the polar vortex to midlatitudes in the lower stratosphere using the high-resolution advection model MIMOSA and effective diffusivity, J. Geophys. Res., 107(D20), 8289, doi:10.1029/2001JD000491, 2002.

Johnson, B. J., Oltmans, S. J., Vömel, H., Smit, H. G. J., Dessler, T., and Kröger, C.: Electrochemical concentration cell (ECC) ozonesonde pump efficiency measurements and tests on the sensitivity to ozone of buffered and unbuffered ECC sensor cathode solutions, J. Geophys. Res., 107(D14), 4210, doi:10.1029/2001JD000557, 2002.

Kaiser, J. W.: Retrieval from limb measurements, Ph.D. Thesis, University of Bremen, Germany, 2001.

Kaiser, J. W., von Savigny, C., Eichmann, K.-U., Noël, S., Bovensmann, H., Frerick, J., and Burrows, J. P.: Satellite Pointing Retrieval from Solar UV-B Radiation Scattered in the Atmosphere by the Earth's limb, Can. J. Phys., 82, 1041-1052, 2004.

Kar, J., Trepte, C. R., Thomason L. W., Zawodny, J. M., Cunnold, D. M., and Wang, H. J.: On the tropospheric measurements of ozone by the Stratospheric Aerosol and Gas Experiment II (SAGE II, version 6.1) in the tropics, Geophys. Res. Lett., 29(24), 2208, doi:10.1029/2002GL016241, 2002.

Kerridge, B., Goutail, F., Bazureau, A., Wang, D.Y., Bracher, A.; Weber, M., Bramstedt, K., Siddans, R., Latter, B. G., Reburn, W. J., Jay, V. L., Dethof, A., and Payne, V. H.: MIPAS Ozone Validation by Satellite Intercomparisons, Proc. Second Workshop on atmospheric chemistry validation of ENVISAT (ACVE-2), ediyted by: Danesy, D., ESA SP-562, 20.1-20.10 2004.

Kley, D., Crutzen, P. J., Smit, H. G. J., Vömel, H., Oltmans, S. J., Grassl H., and Ramanathan, V.: Observations of near-zero ozone concentrations over the convective Pacific, effects on air chemistry, Science, 274, 230-233, 1996.

Lamsal, N., Weber, M., Tellmann, S., and Burrows, J.P.: Ozone column classified climatology of ozone and temperature profiles based on ozonesonde and satellite data, J. Geophys. Res., 109, D20304, doi:10.1029/2004JD004680, 2004.

Llewellyn, E. J., Degenstein, D. A., McDade, I. C., Gattinger, R. L., King, R., Buckingham, R., Richardson, E. H., Murtagh, D. P., Evans, W. F. J., Solheim, B. H., Strong, K., and McConnel, J. C.: OSIRIS-an Application of Tomography for Absorbed Emissions, Remote Sensing, Appl. Phot. Techn., 2, 627-632, 1997.

Llewellyn, E. J., Degenstein, D. A., Lloyd, N. D., Gattinger, R. L., Petelina, S., McDade, I. C., Haley, C. S., Solheim, B. H., von Savigny, C., Sioris, C., Evans, W. F. J., Strong, K., Murtagh, D. P., and Stegman, J.: First results from the OSIRIS instrument on- board Odin, Sodankyla Geophys. Obs. Publ., 92, 41-47, 2003.

Manney, G. L., Michelsen, H. A., Bevilacqua, R. M., Gunson M. R., Irion, F. W., Livesey, N. J., Oberheide, J., Riese, M., Russell III, J. M., Toon, G. C., and Zawodny, J. M.: Comparison of satellite ozone observations in coincident air masses in early November 1994, J. Geophys. Res., 106(D9), 9923-9943, doi:10.1029/2000JD900826, 2001.

Mauldin, L. E., Zaun, N. H., McCormick, M. P., Guy, J. H., and Vaugh, W. R.: Stratospheric Aerosol and Gas Experiment II instrument: A functional description, Opt. Eng., 24, 307-312, 1985.

McCormick, M. P., Chu, W. P., Zawodny, J. M., Mauldin, L. E., and McMaster, L. R.: Stratospheric Aerosol and Gas Experiment III (SAGE III) Aerosol and trace gas measurements from Earth Observing System (EOS), Symp. Aerospace Sensing, Int. Soc. Opt. Eng., 1491-1516, 1991.

McPeters, R. D., Janz, S. J., Hilsenrath, E., Brown, T. L., Flittner, D. E., and Heath, D. F.: The retrieval of $\mathrm{O}_{3}$ profiles from limb scatter measurements: Results from the Shuttle Ozone Limb Sounding Experiment, Geophys. Res. Lett., 27, 2597-2600, 2000.

Meijer, Y., Swart, D. P. J., Allaart, M., Andersen, S. B., Bodeker, G., Boyd, I., Braathen, G., Calisesi, Y., Claude, H., Dorokhov, V., von der Gathen, P., Gil, M., Godin-Beekmann, S., Goutail, F., Hansen, G., Karpetchko, A., Keckhut, P., Kelder, H. M., Koelemeijer, R., Kois, B., Koopman, R.,.Kopp, M. G., Lambert, J.-C., Leblanc, T., McDermid, I. S., Pal, S., Schets, H.,Stubi, R., Suortti, T., Visconti, G., and Yela, M.: Pole-to-pole validation of Envisat GOMOS ozone profiles using data from groundbased and balloon sonde measurements, J. Geophys. Res., 109, D23305, doi:10.1029/2004JD004834, 2004.

Morris, G. A., Gleason, J. F., Russell III, J. M., Schoeberl, M. R., and McCormick, M. P.: A comparison of HALOE V19 with SAGE II V6.00 ozone observations using trajectory mapping, J. Geophys. Res., 107(D13), 4177, doi:10.1029/2001JD000847, 2002.

Murtagh, D. P., Frisk, Urban, U., Merino, F., Ridal, F., Jonsson, M., Stegman, A. J., Witt, G.,Eriksson, P., Jiménez,C., Megie, G., de la Noë, J., Ricaud, P., Baron, P., Pardo, J.R., Hauchcorne, A., Llewellyn, E. J., Degenstein, D. A., Gattinger, R. L., Lloyd, N. D., Evans, W. F. J., McDade, I. C., Haley, C. S., Sioris, C., von Savigny, C., Solheim, B.H., McConnell, J. C., Strong, K., Richardson, E. H., Leppelmeier, G. W., Kyrölä, E., Auvinen, H., and Oikarinen, L.: An overview of the Odin Atmospheric Mission, Can. J. Phys, 80, 309-319, 2002.

Orphal, J.: A critical review of the absorption cross-sections of $\mathrm{O}_{3}$ and $\mathrm{NO}_{2}$ in the ultraviolet and visible, J. Photochem. Photobiol., A Chem., 157, 185-209, 2003.

Petelina, S. V., Llewellyn, E. J., Degenstein, D. A., Lloyd, N. D., Gattinger, R.L., Haley, C.S., von Savigny, C., Griffioen, E., McDade, I. C., Evans, W. F. J., Murtagh, D. P., and de La Noe, J.: Comparison of the Odin/OSIRIS stratospheric ozone profiles with coincident POAM III and ozonesonde measurements, Geophys. Res. Lett., 31, L07104, doi:10.1029/2003GL019299, 2004.

Pommereau, J.-P. and Piquard, J.: Ozone, Nitrogen dioxide and Aerosol vertical distributions by UV-visible solar occultation from balloons, Geophys. Res. Lett., 21, 1227-1230, 1994.

Pommereau, J.-P., Garnier, A. Held, G., Gomes, A.-M., Goutail, F., Durry, G., Borchi, F., Hauchecorne, A., Montoux, N., Cocquerez, P., Letrenne, G., Vial, F., Hertzog, A., Legras, B., Pisso, 
I., Pyle, J. A., Harris, N. R. P., Jones, R. L., Robinson, A., Hansford, G., Eden, L., Gardiner, T., Swann, N., Knudsen, B., Larsen, N., Nielsen, J., Christensen, T., Cairo, F., Pirre, M., Marécal, V., Huret, N., Rivière, E., Coe, H., Grosvenor, D., Edvarsen, K., Di Donfrancesco, G., Ricaud, P., Berthelier, J.-J., Godefroy, M., Seran, E., Longo, E., and Freitas, S.: An overview of the HIBISCUS campaign, Atmos. Chem. Phys. Discuss., 7, 2389-2475, 2007 ,

http://www.atmos-chem-phys-discuss.net/7/2389/2007/.

Ridolfi, M., Carli, B., Carlotti, M., von Clarmann, T., Dinelli, B. M., Dudhia, A., Flaud, J.-M., Höpfner, M., Morris, M. P., Raspollini, P., Stiller, G., and Wells, R. J.: Optimized forward and retrieval scheme for MIPAS near real-time data processing, Appl. Opt., 39(8), 1323-1340, 2000.

Rogers, C. D.: Retrieval of atmospheric temperature and composition from remote measurements of thermal radiation, Rev. Geophys., 14, 609-624, 1976.

Rozanov, A., von Savigny, C., Bovensmann, H., Bracher, A., and Burrows, J. P.: Description of the SCIAMACHY scientific $\mathrm{O}_{3}$ and $\mathrm{NO}_{2}$ profile data set for September/October 2002, Report EU Project TOPOZ III, 72 pp., 2003.

Russel III, J. M., Gordley, L. L., Park, J. H., Drayson, S. R., Hesketh, W. D., Cicerone, R. J., Tuck, A. F., Frederick, J. E., Harries, J. E., and Crutzen, P. J.: The HALogen Occultation Experiment, J. Geophys. Res., 98(D6), 10 777-10 797, 1993.

SAGE III Algorithm Theoretical Basis Document: Solar and Lunar Algorithm, NASA Langlay Research Center, 475-00-108, Version 2.1, 26 March 2002, http://eospso.gsfc.nasa.gov/eos_homepage/for_scientists/atbd/ docs/SAGE\%20III/atbd-sage-solar-lunar.pdf.

Segers, A. J., von Savigny, C., Brinksma, E .J., and Piters, A. J. M.: Validation of IFE-1.6 15 SCIAMACHY limb ozone profiles, Atmos. Chem. Phys., 5, 3045-3052, 2005, http://www.atmos-chem-phys.net/5/3045/2005/.

Shettle, E. P. and Anderson, S.bM.: New visible and near IR ozone cross-sections for MODTRAN, in: Proc. 17th Annual Review, Conf. on Atmospheric Transmission Models, edited by: Gail, P., Vol. AD-A295591, 1994.

Stratospheric Processes and their Role in Climate (SPARC), Assessment of trends in the vertical distribution of ozone, Report 1, edited by: Harris, N., Hudson, R., and Philips, C., World Meteorological Organisation, Rep \#43, 1998.

Thomason, L. W., Chu, W. P., and Pitts, M. C.: The Stratospheric Aerosol and Gas Experiment III, Abstract 22nd General Assembly IUGG (http://www.iugg.org/assemblies/1999birmingham/), Birmingham, UK, July 1999.
Thompson, A. M., Witte, J. C., McPeters, R. D., Oltmans, S. J., Schmidlin, F. J., Logan, J. A., Fujiwara, M., Kirchhoff, V. W. J. H., Posny, F., Coetzee, G. J. R., Hoegger, B., Kawakami, S., Ogawa, T., Johnson, B. J., Vömel, H., and Labow, G.: Southern Hemisphere Additional Ozonesondes (SHADOZ) 1998-2000 tropical ozone climatology, 1. Comparison with TOMS and Ground-based Measurements, J. Geophys. Res., 108(D2), 8239, doi:10.1029/2001JD000967, 2003.

Urban, J., Baron, P., Lautié, N., Dassas, K., Schneider, N., Ricaud, P., and de La Noë, J.: MOLIERE (v5): A versatile forwardand inversion model for the millimeter and sub-millimeter wavelength range, J. Quant. Spectro. Radiat. Transfer, 83(3-4), 529554, 2004.

Urban, J., Lautié, N., Le Flochmoën, E., Jiménez, C., Eriksson, P., de La Noë, J., Dupuy, E., Ekström, M., El Amraoui, L., Frisk, U., Murtagh, D., Olberg, M., and Ricaud, P.: Odin/SMR limb observations of stratospheric trace gases: Level 2 processing of $\mathrm{ClO}, \mathrm{N}_{2} \mathrm{O}, \mathrm{HNO}_{3}$, and $\mathrm{O}_{3}$, J. Geophys. Res., 110, D14307, doi:10.1029/2004JD005741, 2005.

von Clarmann, T., Glatthor, N., Grabowski, U., et al.: Retrieval of temperature and tangent altitude pointing from limb emission spectra recorded from space by MIPAS, J. Geophys. Res., 108(D23), 4736, doi:10.1029/2003JD003602, 2003.

von Savigny, C., Haley, C. S., Sioris, C. E., McDade, I. C., et al.: Stratospheric ozone profiles retrieved from Limb scattered sunlight radiance spectra measured by the OSIRIS instrument on the Odin satellite, Geophys. Res. Lett., 30, 1755, doi:10.1029/2002GL016401, 2003.

von Savigny, C., Kaiser, J. W., Bovensmann, H., McDermid, I. S., Leblanc, T., and Burrows, J. P.: Spatial and Temporal Characterization of SCIAMACHY Limb Pointing Errors During the First Three Years of the Mission, Atmos. Chem. Phys., 5, 2593-2602, 2005 , http://www.atmos-chem-phys.net/5/2593/2005/.

Wang, H. J., Cunnold, D. M., Thomason, L. W., Zawodny, J. M., and Bodeker, G. E.: Assessment of SAGE version 6.1 ozone data quality, J. Geophys. Res., 107(D23), 4691, doi:10.1029/2002JD002418, 2002.

Warshaw, G. D., Desaulniers, D.-L., and Degenstein, D.: Optical design and performance of the Odin UV/visible spectrograph and infrared imager instrument, Proc. 10th Annual AIAA/USU Conference on Small Satellites, 1996. 